\title{
Corporate Relocation in Venture Capital Finance
}

\author{
Douglas Cumming \\ Grant Fleming \\ Armin Schwienbacher
}

This paper introduces an analysis of international relocation decisions of venture capital (VC)-backed companies. Relocations to the United States are motivated by economic conditions as well as an improvement in the laws of the country in which the entrepreneurial firm is based. Relocations to the United States yield much greater returns to Asia-Pacific VCs than investing in companies already based in the United States at the time of VC investment. Further, more experienced Asia-Pacific VCs have greater success with their investee relocations to the United States, and these relocations yield higher returns relative to staying in their country of origin.

\section{Introduction}

One of the most striking developments in venture capital (VC) over the last 15 years is the increasing internationalization of entrepreneurship and entrepreneurial finance (Allen \& Song, 2003; Baker, Gedajlovic, \& Lubatkin, 2005; Fernandez \& Nieto, 2006; Lockett, Wright, Burows, Scholes, \& Paton, 2008; Manigart et al., 2000; Manigart, Korsgaard, Folger, Sapienza, \& Baeyens, 2002; Manigart, DeWaele, et al., 2002; Manigart et al., 2006; Megginson, 2004; Sapienza, Autio, George, \& Zahra, 2006; Sapienza, De Clercq, \& Sandberg, 2005; Sapienza, Manigart, \& Vermeir, 1996; Wright et al., 2004; Wright, Pruthi, \& Lockett, 2005; Zahra, Ireland, \& Hitt, 2000). Venture capitalists operate across countries and time zones, providing capital and skills to entrepreneurial firms competing in global markets. This is especially the case in early stage VC where technology transcends geographic boundaries. The increasing globalization of the VC industry and the central role of property rights, legal systems, and economic conditions in facilitating successful VC exits have led to new trends in venture capitalist behavior. Venture capitalists based in countries with weak economic conditions and poor legal protections face particularly pronounced risks associated with investing in early stage and high-tech companies. In order to mitigate such risks, a venture capitalist may relocate an entrepreneurial firm (i.e., at least part of the firm's operations) to a country with stronger legal protections and a more liquid exit market after the venture capitalist's initial investment but before exit. Such relocation involves incorporation of a new company in the destination country and the issuing of new private equity to the venture capitalist. Given the importance of legal protection for these firms, the location choice of new ventures has

Please send correspondence to: Douglas Cumming, tel.: +416-736-2100 ext. 77942; e-mail: Douglas. Cumming@gmail.com. 
become a key strategic decision. As well, a venture capitalist may invest across borders by purchasing equity in private entrepreneurial firms based in countries with stronger economic conditions and legal protections. Such behavior has increased over time as finance markets in general have become more interconnected.

The capital investment process involves venture capitalists nurturing entrepreneurial firm management through company formation, defining and protecting key technology, fostering operational growth, adding value through their human capital, providing access to contacts and networks, and positioning the company for exit (Batjargal, 2007; Coviello, 2006). Successful VC-backed companies facilitate the creation of new entrepreneurial ventures as entrepreneurial skills are spawned from the successful entrepreneurs to the new start-ups (Gompers, Lerner, \& Scharfstein, 2005). However, there are vast differences between the size of emerging and developed country VC markets, and these differences are more pronounced than that for other sectors of the economy (Lerner \& Schoar, 2005). Zacharakis, McMullen, and Shepherd (2007) provide evidence that VCs in different countries use information in different ways, with market-based information (hard information) being proportionately more often used in the United States as compared with emerging countries (see also Zacharakis \& Shepherd, 2001, 2003). In this paper, we empirically show that venture capitalists in countries with weak legal and economic conditions often relocate their investee firms to the United States. The firms that are relocated do better than staying in their country of origin. Differences in entrepreneurship and economic growth are therefore perpetuated in emerging countries as relocation implies less spillover of successful VC-backed companies within emerging countries.

This raises important questions about the capability of entrepreneurs to operate transnationally and attract financial players who may facilitate international expansion of new ventures. Transnational entrepreneurs may in fact have the largest impact on an economy as they are likely to exhibit significant growth potential. At the same time, they are presumably more flexible in terms of location, given their international exposure. A better understanding of how transnational entrepreneurship interacts with financing sources is critical to assess the incentives that drive these entrepreneurs.

In this paper, we provide an analysis of why venture capitalists seek to relocate investee companies in countries with stronger legal protections and economic conditions. We complement this analysis by also empirically analyzing venture capitalists' decisions to invest in early stage and high-tech companies, as well as the decision to invest in companies already located overseas at the time of initial investment. Our data allow analysis of the success of international investment strategies as determined by the venture capitalists' return to investment. We study a sample of 468 private companies that were financed by 53 venture capitalists based in 12 Asia-Pacific countries (Australia, China, Hong Kong, India, Indonesia, Malaysia, New Zealand, Philippines, Singapore, South Korea, Taiwan, and Thailand). Among the companies financed, 49 were relocated to the United States from the Asia-Pacific after the companies were financed by an Asia-Pacific VC fund, and 68 companies were already based in the United States at the time they were financed by an Asia-Pacific VC fund.

We draw inspiration from previous work in the international business studies literature that investigates international joint venture sell-offs (Meschi, 2005) and foreign direct investment more generally (Albuquerque, Loayza, \& Servén, 2005). Buckley et al. (2007) provide a complementary study of international investments of Chinese corporations. Goerzen and Makino (2007) show that firms that internationalize early in their core business outperform their peers that internationalize in unrelated activities. There is also evidence that foreign firms that cross-list in the United States are worth more than when only having a foreign listing (Doidge, Karolyi, \& Stulz, 2004). Many of these studies 
focus on the benefits to international investment for public firms due to differences in financial markets, liquidity, and superior legal and accounting systems. There is little work to date on the relocation strategies of venture capitalists. We argue that the venture capitalists' motivations for relocating companies place particular emphasis on legal protections to shareholders and economic conditions to enhance firm value before exiting the investment. We consider the "law and finance variables" from La Porta, Lopez-de-Silanes, Shleifer, \& Vishny (1997, 1998, 2000), including the efficiency of the judicial system, the rule of law, corruption, risk of expropriation, risk of contract repudiation, and shareholder rights (hereafter "the law and finance factors"). Taken together, these factors comprise the "legality" in a country (Berkowitz, Pistor, \& Richard, 2003). We also consider differences in gross domestic product (GDP) and population as an alternative motivation for relocations as firms (and their VC equity holders) may want to be located closer to potential markets and customers in order to grow the business and increase the probability of a profitable exit/sale of the business.

Our results support the notion that international business activities of VCs are influenced by differences in legality and economic conditions. First, we show that entrepreneurial firms based in riskier high-tech industries are more likely to receive private equity finance in countries with higher legality indices and stronger economic conditions. Second, we show that relocating equity positions from Asia-Pacific countries are typically to the United States, and such relocations are more likely from emerging markets with both lower legality indices and weaker economic conditions.

Third, the data indicate that active strategies to move equity positions from outside the United States into the United States yield much greater returns to Asia-Pacific venture capitalists than investing in companies already based in the United States at the time of initial investment. The average (median) fully realized internal rate of return (IRR) on the investment in a company that moved to the United States from the Asia-Pacific was $112.4 \%$ $(12.9 \%)$, compared with an average (median) IRR of $-15.1 \%(-0.5 \%)$ for investments in companies already based in the United States at the time of investment. Excluding investments in firms that were initially based in the United States, and investments in firms that were moved to the United States, the average (median) return on investment was $27.8 \%$ (20.1\%). ${ }^{1}$ More experienced Asia-Pacific venture capitalists (based on various proxies for experience, such as fund size and whether the VC managers have U.S. VC experience) have more success with their equity relocations to the United States, and these investment strategies yield higher returns relative to keeping their positions in their country of origin.

This paper is organized as follows. The next section provides an overview of the related literature and our hypotheses. Data, econometric methodology, definitions, and summary statistics are then presented. Thereafter, we present the results of our multivariate empirical analyses. The last sections discuss limitations, future research, practical implications, and policy implications.

\section{Literature and Hypotheses}

At a general level, we posit that relocation decisions of VC-backed companies may be explained by institutional factors, VC firm level factors, and portfolio firm level factors. In

1. The large difference between mean and median indicates that the distribution of returns is clearly not symmetric. This is in line with other studies that have documented that IRR of venture capital investments are skewed, with many failures and a few deals making up a significant part of the returns in the venture capital industry. 
the subsequent sections, we discuss each in turn. We extend the set of predictions identified in the literature on relocation choices by examining the particular impact of VC presence as active investors in new ventures.

\section{Institutional Factors Affecting Relocation}

A growing literature in entrepreneurship involves the internationalization of new ventures (for a review of this literature see Zahra, 2005). Oviatt and McDougall (1994) examine the internationalization of new ventures, and the strategies new firms adopt in order to access foreign markets. A central issue is the growth capability of firms in order to become internationally active. Their theory discusses how companies start locally (mainly nationally), then enter markets in neighbor countries and ultimately become globally active. By contrast, Buckley and Hashai (2004) argue that the location configuration of the firm is best analyzed through a global system model. In this view, the internationalization of new ventures should be seen as the outcome of optimal decisions on where best to locate various value-adding activities. Ownership has also been found to influence the location/relocation decision process. Fernandez and Nieto (2006), for example, find that variations in ownership (e.g., family businesses) can critically shape the internationalization strategy of firms. The formation of international new ventures necessarily relies on the formation of a business network of stakeholders, providing "international social competence" crucial in the successful international development of the firm and in creating sustainable competitive advantage (Phelan, Dalgic, Li, \& Sethi, 2006).

Recent international business studies have focused on determining whether some companies are "born global" (Andersson, 2004; Knight \& Cavusgil, 1996, 2004; Madsen \& Servais, 1997; Oviatt \& McDougall, 1995; Rialp, Rialp, \& Knight, 2005). Transnational entrepreneurs seek to create sustainable competitive advantage for themselves by locating and operating in multiple countries and are often formed with an international vision from the start. Born global companies were originally thought to be a feature of the rapid development of information technology, the ease of global communication, homogeneity of markets, and a larger stock of "international" entrepreneurs. Thus, certain industries (e.g., information technology, software, and services) were more likely to be born global. However, international new ventures have also been identified in other industries (see Madsen \& Servais, 1997), and their existence may be as much determined by entrepreneurial networks as industry, product, or market characteristics (Phelan et al., 2006).

A related finance literature shows cross-listing allows firms to avoid cross-border barriers to investment such as regulation and information asymmetries. Market segmentation and lack of investor recognition increases the firm's cost of capital. Several studies have shown that cross-listing is associated with a stock price increase for the firm on their domestic exchange (i.e., the country of origin) and a lower cost of capital (Foerster \& Karolyi, 1993, 1999; Jayaraman, Shastri, \& Tandon, 1993). Cross-listing may result in improved liquidity, also lowering the cost of capital. The dual listed firm should experience lower transaction costs of trading, lower bid-ask spreads, and higher trading volumes (Domowitz, Glen, \& Madhavan, 1998; Foerster \& Karolyi, 1998). Cross-listing allows the foreign firm to operate in an environment with stronger shareholder protection and greater disclosure requirements, which improves valuations and ability to raise external capital (Benos \& Weisbach, 2004; Doidge et al., 2004; Reece \& Weisbach, 2002). All these studies, however, focus on the financial implications for publicly listed firms. By contrast, we examine how venture capitalists relocate (all or part) of a private firm to another country. 
We conjecture that a venture capitalist will relocate a company in order to facilitate an improvement in the governance of the company, by virtue of better legal protections associated with the investment in terms of the efficiency of the judicial system, the rule of law, corruption, risk of expropriation, risk of contract repudiation, and shareholder rights ("the law and finance factors" from Berkowitz et al., 2003; La Porta et al., 1997, 1998, 2000; see also Guler \& Guillen, 2006). Relatedly, hard market-based information is more reliable and valuable to venture capitalists in countries offering improved governance through better protection (see Zacharakis et al., 2007) on the use of market information for decision making in rules-based economies), and the institutional context can facilitate entrepreneurial effort (Bowen \& De Clercq, 2008). Better legal protections also facilitate transaction certainty upon exit, whether such exits are via initial public offerings (IPOs) or acquisitions (Cumming, Fleming, \& Schwienbacher, 2006). It is easier for the venture capitalist to sell an investment based in a country with stronger legal conditions because the new purchasers of the firm (e.g., new public shareholders in the case of an IPO exit) face less information asymmetry facilitated by stronger disclosure requirements and related legal protections (Shleifer \& Wolfenzon, 2002). These findings support a strong link between investor protection induced by a better developed legal system and governance, inducing relocation in countries offering better protection.

Hypothesis 1: VC-backed companies located in countries with less-developed law and financial systems are more likely to relocate to countries with more-developed law and financial systems, in order to improve governance, mitigate information asymmetries at the time of exiting the investment, and improve the expected rate of return of the investment.

As a corollary to Hypothesis 1, we would expect countries with better legal systems to be more likely to have investors financing earlier stage and high-tech firms. Earlier stage and high-tech firms exhibit more pronounced information asymmetries and agency costs. As higher quality legal environments mitigate such information asymmetries and agency costs by offering better protection to investors, it is natural to expect external capital from VC investors in countries with better legal standards. In the empirical analyses in the following sections, we assess the likelihood of early stage and hightechnology investment in relation to law quality to ascertain the importance of law quality at the time of investment. If law quality is important at the time of exit, as predicted by Hypothesis 1, then it would also be important at the time of investment. ${ }^{2}$

Importantly, Hypothesis 1 is not specified for "cross-border transactions" at the time of first investment. In contrast to relocated VC-backed companies, cross-border transactions at first $\mathrm{VC}$ investment may in fact be characterized as having greater information asymmetries and agency problems. It is more difficult for a venture capitalist to carry out due diligence the greater the distance between the venture capitalist and the entrepreneur at time of first investment (Gompers \& Lerner, 1999). As well, all else being equal entrepreneurs prefer venture capitalists to be proximate in order to potentially benefit from

\footnotetext{
2. Alternatively, it is possible that some combinations of countries may do better than others, irrespective of their difference of legal quality. Moreover, a dual institutional affiliation may give companies a distinctive legal environment. The approach adopted here is based on the legality index that orders the countries' legal system on a scale and only considers differences in the index to be relevant. This approach allows us to compare countries directly. The alternative approach would lead to comparing combinations of countries, allowing for a complementary view on cross-country differences in legal quality. It would however require more detailed information on legal aspects of each country and more observations. We thank the guest editor for pointing this out.
} 
value-added assistance provided by the venture capitalist (see, e.g., Gompers \& Lerner; Sapienza et al., 1996). In our empirical analyses in the subsequent sections, we distinguish between relocated investments and cross-border investments.

In addition to legal factors prompting relocation, a decision to relocate a company may also be driven by a desire (or need) for the company to be located closer to customers. A body of research relates to the physical relocation of companies to secure real locational advantages associated with lower factor prices, higher quality resources, and/or greater product market opportunities. Another possibility is that entrepreneurs want to be located in the United States due to the learning opportunities for new ventures both in terms of technology and market-related issues (see Sapienza et al., 2006). The product-cost relocation studies examine public companies shifting all or part of their premises to alternative jurisdictions. For example, Tirtiroglu, Bhabra, and Lel (2004) analyze the impact of Quebec's drive for sovereignty from Canada as a source of political uncertainty for the decision of Canadian corporations to relocate elsewhere. They provide empirical evidence of positive stock market returns for Quebec corporations relocating to other Canadian provinces, suggesting improvements in competitive position and real financial returns. Chan, Gau, and Wang (1995) also examine the stock market reaction to announcements of corporate relocations. Chan et al. evidence a positive reaction if the motive of relocation is associated with business expansion or cost savings and if the prospects of the corporation are favorable. Along similar lines, Ghosh, Rodriguez, and Sirmans (1995) find that stock market reaction is positive when the relocation of headquarters is associated with cost savings. Our analysis of relocations differs from these studies since it is, to our knowledge, the first one to study business relocation of VC-backed companies. For VC-backed companies that typically do not have any production operations established at the time of $\mathrm{VC}$ investment, the primary motive for relocation is not a reduction in production costs, but rather to facilitate the sale of the company at the time of VC exit. To this extent, this hypothesis is consistent with the born global literature where international new ventures will attempt to create and maintain competitive advantages in valuable niches in global (or core) markets from an early stage in their existence. Relocation of VC-backed companies, therefore, is more likely to countries with not only better laws but also stronger economic conditions. Two measures are GDP per capita (capturing whether a country is "rich") and size of population (to capture size of the local market).

Hypothesis 2: VC-backed companies located in poor countries and with smaller populations are more likely to relocate to countries with stronger economic conditions and greater populations in order to be closer to potential customers at the time of exit and improve the expected rate of return of the investment.

As a corollary to Hypothesis 2, we would likewise expect economic conditions (both population wealth and size of population) to be important at the time of investment. Similar to the corollary to Hypothesis 1 discussed previously, we test the role of economic conditions at the time of investment in our empirical analyses.

Note that we do not have firms in the dataset with nontrivial production operations established at the time of first VC investment, given the firms were in their earlier stages of development at the time of first investment. We are therefore unable to formally test the production hypothesis as distinguished from the location hypothesis. Future research might be able to assess further differences therein with later stage companies and data on production costs in different locations. 


\section{VC Firm Level Factors Affecting Relocation}

$\mathrm{VC}$ is a distinct form of financial intermediation by virtue of the value-added activities provided by the fund managers to their investee companies (e.g., Hsu, 2004; Manigart et al., 2006; Sapienza et al., 1996; Wright \& Lockett, 2003). Fund managers provide financial, administrative, marketing, human resource, and exit advice, and typically sit on the board of directors of the entrepreneurial firms in which they invest. In view of the importance of value-added active investing in distinguishing venture capitalists and the fact that investor characteristics affect the value-added provided (e.g., Wright \& Lockett), it is natural to expect investor characteristics might influence international relocation decisions. Well-established and experienced venture capitalists, particularly venture capitalists with experience operating in the country of intended destination, will have better connections to legal and accounting advisors, strategic advisors, investment banks, and other networks that could help bring the investment to fruition (Jääskeläinen \& Maula, 2005).

Venture capitalists' experience may be proxied by a variety of different variables. Commonly used proxies in the literature include fund capital per the number of fund managers, as well the number of years of experience of the fund managers, and stage and sector specialization of the fund (see, e.g., Gompers \& Lerner, 1999; Wright \& Lockett, 2003). Further, there are differences between private independent versus captive funds; captive funds (owned by a bank) typically face more constraints on their operations, have less efficient incentive pay structures for their managers, and are less stable entities (Gompers \& Lerner). Captive funds are therefore less likely to have skills, networks, and incentives to facilitate international relocation of their investees. We expect these proxies for $\mathrm{VC}$ fund manager relocation decisions to be correlated with the decision to and success of relocation.

Hypothesis 3: More experienced VCs and private independent VCs are more likely to internationally relocate their investments and improve the expected rate of return of the investment.

\section{Portfolio Firm Level Factors Affecting Relocation}

In addition to venture capitalist characteristics, portfolio firm characteristics might influence the desire to relocate. VC involves the financing of small fast growing companies that often have a pronounced need for protecting their intellectual property portfolio (Ginarte \& Park, 1997). As such, we may expect entrepreneurial firms in high-tech industries to benefit more from relocating their activities so that their intellectual property rights receive greater protection. Further, upon sale of those rights to new owners at the time of exit, such rights will be valued more where the country's laws provide greater certainty in protection of such rights (as well as legal recourse in the event of misrepresentation of the extent and/or value of the intellectual property held by the entrepreneurial firm).

We may further expect that venture capitalists relocate investees that are in earlier stages of development at the time of investment (similar to Goerzen \& Makino, 2007). Earlier stage firms will have less well-established strategic ties to other related parties in their country of domicile (such as related suppliers and distribution networks for the company's products). The move of a firm earlier in its life cycle may also simply be less costly relative to a more established one. This will allow the venture capitalists' equity position to be valued in the new market from an early stage, reducing information asymmetries and improving likelihood of further capital raisings (De Clercq \& Sapienza, 2005; De Clercq, Sapienza, \& Crijns, 2005). 
Hypothesis 4: Venture capitalists are more likely to internationally relocate their earlier stage and high-tech investee firms and thereby improve the expected rate of return of these investments.

In sum, we test institutional (legal and market factors), $\mathrm{VC}$ firm level (experience and value-added), and portfolio firm level factors (high-tech and stage of development) in the decision to relocate $\mathrm{VC}$-backed companies and the success of such relocations. We control for a variety of factors that are well known to influence the outcomes of VC-backed companies in our empirical analyses. The data and empirical tests are described in the subsequent sections.

\section{Data and Econometric Methodology}

\section{Data Description}

This paper analyzes a hand-collected dataset from venture capitalists operating in the Asia-Pacific region. Sample selection began with a full list of major VC firms obtained from the Asian Venture Capital Journal's Annual Guides. We then collected VC firmspecific and investee firm-specific information from three publicly available databases: Asian Venture Capital Journal, Australian Venture Capital Journal, and VentureXpert (Venture Economics). This data included fund characteristics such as ownership of the VC firm, experience of professionals, sector and stage focus, and funds-under-management. Also available (in some instances) were investee firm financial characteristics, method of exit, and returns. The next step in the process involved one of the authors contacting the VC firms to supplement publicly available data. This allowed us to increase the amount of information on returns and unexited investments. Finally, we collected legality factors and public market returns from traditional sources. In short, we do not rely on VentureXpert or any other exclusive source, but rather use a variety of sources to maximize the amount of data and information we could obtain. We do not believe our data exhibit bias, as discussed subsequently. The final sample comprised data from $53 \mathrm{VC}$ funds involving 468 investee companies and 12 countries in the Asia-Pacific region: Australia, China, Hong Kong, India, Indonesia, Malaysia, New Zealand, Philippines, Singapore, South Korea, Taiwan, and Thailand. The data span the years 1989-2001. The data exclude buyout and turnaround transactions (as described in Wright, Hoskisson, Busenitz, \& Dial, 2001), but include early stage (seed, start-up, early, and expansion stages) and late stage (mezzanine stages) of investment. We do not distinguish between different types of early stage investment as these are vague concepts that are not consistently defined by VC funds across countries.

We believe that the data are reasonably representative of venture capitalists operating in the Asia-Pacific region. The data are similar in size and scope to other hand-collected datasets in academic VC research (see, e.g., Lerner \& Schoar, 2005, for a sample of 210 private equity transactions in developing countries). It is difficult to know exactly how representative the exit frequencies are from each of the counties in the dataset because the reporting of data from Asia-Pacific markets is in a nascent stage of development, and the extent of coverage is unknown. Even in relatively more developed countries in the Asia-Pacific region such as Singapore, the available data from other sources has only recorded the frequency of venture-backed IPOs and non-IPO exits (that is, grouping acquisitions, secondary sales, buybacks, and write-offs all in the same category; see Wang \& Sims, 2001) and scant other information about the investments and exits. Our data are also comparable with those used in corporate finance work in Asia more generally; see, 
e.g., Claessens, Djankov, and Lang (2000). We cannot be reasonably certain about aggregate country level data for any of the Asia-Pacific countries, which is in contrast to the U.S. VC market. (Australia is in part one exception to this statement, but this paper considers much more detailed data than that which is available on an industry-wide basis in the Australian VC market.) As such, we are unable to provide comparisons to industrywide data (as typically done for U.S.-only datasets; see Gompers \& Lerner, 1999). Our inability to provide reliable industry-wide comparisons on variables of interest is a limitation of almost all VC research studies with international samples outside United States (again, see, e.g., Lerner \& Schoar).

\section{Variable Definitions}

Our econometric models have specified five sets of factors that potentially influence the venture capitalists' decision to undertake cross-border equity investment: legal and institutional conditions; VC fund characteristics; entrepreneurial firm and transaction characteristics; market conditions; and exit status. Table 1 provides definitions of each variable used in our study.

The majority of VC fund and entrepreneurial firm/transaction characteristics are coded from the raw data provided by the venture capitalists and publicly available sources. The legality index (our core explanatory variable) is a weighted average of legal factors first analyzed by La Porta et al. (1997, 1998, 2000): efficiency of judicial system, rule of law, corruption, risk of expropriation, risk of contract repudiation, and shareholders' rights (see Table 2). Given the relatively stable nature of the quantitative measures used in this area of research, data are drawn from the La Porta studies. We then weigh the data using the outcome of principal components analysis undertaken by Berkowitz et al. (2003). Market conditions are measured as the country-specific return (log difference of period t over period t-1) using the Morgan Stanley Capital International (MSCI) country indices. We introduce two dummy variables to control for investments and exits made during the VC "bubble" between 1997 and 2001.

\section{Summary Statistics}

Our variables of interest relate to legal and institutional conditions, VC fund characteristics, entrepreneur and transaction characteristics, market conditions, and exit status. The data are summarized in Tables 2 and 3 and Figures 1 and 2. Figure 1 provides a histogram of returns by exit status. There are "full" and "partial" VC exits for each exit vehicle (Cumming \& MacIntosh, 2003; Gompers \& Lerner, 1999; Megginson \& Weiss, 1991; Neus \& Walz, 2005). A full IPO, secondary sale, and buyback involves the sale of $100 \%$ of the venture capitalist's interest within 1 year from the date of the first disposition; a partial exit takes more than 1 year. A full acquisition involves a sale for cash; a partial acquisition involves the receipt of (typically illiquid) shares. A full write-off is a complete liquidation of the investment; a partial write-off is a write-down of the book value of the investment. Figure 1 shows that most realized an IRR of less than $100 \%$. Some ventures nevertheless generated returns up to $1,000 \%$. Figure 2 shows the percentage of data points of venture investments and exit by year and relocation. It indicates that our sample is fairly spread over the considered time period. That we have exited, partially exited, and unexited investments in our sample is useful for sample selection issues. The histograms of returns (Figure 1) and of investment and exit years (Figure 2) are broadly consistent with other international data sets (see, e.g., Cumming \& Walz, 2009; Hege, Palomino, \& 


\author{
Legal and institutional conditions \\ Legality index of country at \\ exit (or investment) \\ GDP at exit (or investment) \\ Population \\ Entrepreneur moved to the \\ United States \\ Fund characteristics \\ Captive VC \\ VC with U.S. experience \\ Years experience at the time of exit
}

Sector specialist dummy variable Stage specialist dummy variable Portfolio size/fund manager

\section{Fund number}

Fund capital/fund manager

Entrepreneur and transaction characteristics Hi-tech entrepreneur

Early stage entrepreneur

Syndication

Duration of investment

Market conditions

MSCI

Exit year dummies

Investment year dummies

\section{Exit status}

Exited investment

Fully exited investment
Weighted average of following factors (based on Berkowitz et al., 2003): efficiency of judicial system, rule of law, corruption, risk of expropriation, risk of contract repudiation, shareholder rights. Higher numbers indicate "better" legal systems.

The GDP (in thousands of real 2000 USD) in the country of entrepreneur domicile at exit (or investment).

The population (in thousands) in the country of entrepreneur domicile at exit.

A dummy variable equal to 1 if the entrepreneur was initially based in the Asia-Pacific region at the time of first VC investment, but relocated to the United States.

A dummy variable equal to 1 if the lead investor is a corporate or bank captive VC.

A dummy variable equal to 1 if the lead investor has U.S. VC experience.

The total number of years of experience that all the VC fund managers have at the time of exiting the investment. The summary statistics also report the average number of years of experience per fund manager at the time of initial investment.

A dummy variable equal to 1 if the $\mathrm{VC}$ fund has a sector specialization focus.

A dummy variable equal to 1 if the $\mathrm{VC}$ fund has a stage specialization focus.

The number of entrepreneurial firms in the $\mathrm{VC}$ fund portfolio divided by the number of $\mathrm{VC}$ managers working for the fund.

The number of funds that the VC firm managed prior to the current VC fund.

The total fund capital (in 2000 USD) divided by the number of fund managers.

A dummy variable equal to 1 if the entrepreneur is in a high-tech industry (e.g., biotechnology, electronics, computers, etc.)

A dummy variable equal to 1 if the entrepreneur is in an early stage of development (defined to include seed, start-up, and expansion stage investments across the Asia-Pacific countries. More precise definitions of stage of development are not possible given inconsistencies of reporting stages across the Asia-Pacific regions. Generally, early stage refers to companies that have not yet developed to profitable levels.)

A dummy variable equal to 1 if there was more than one VC fund from different VC organizations that financed the entrepreneurial firm.

The number of months from the date of first VC investment to the date of exit (or to December 2001 if unexited).

The country-specific Morgan Stanley Capital International Index (returns are computed for the periods as indicated in the subsequent tables).

Dummy variables equal to 1, particularly for years 1997-2001, where exit occurred at that time.

Dummy variables equal to 1, particularly for years 1997-2001, where investment occurred at that time.

A dummy variable equal to 1 if the investment was fully or partially exited by Dec 2001 .

A dummy variable equal to 1 if the investment was fully exited by Dec 2001 .

GDP, gross domestic product; VC, venture capital; MSCI, Morgan Stanley Capital International.

Schwienbacher, 2009). The frequency of observations for each exit type from each country is indicated in Table 2, alongside the Legality indices.

Table 3 provides information on the country location of entrepreneurial firms at time of VC investment and at time of exit by the venture capitalist. In absolute numbers, Taiwan and Australia are the most represented countries in terms of firms. All but three of the 


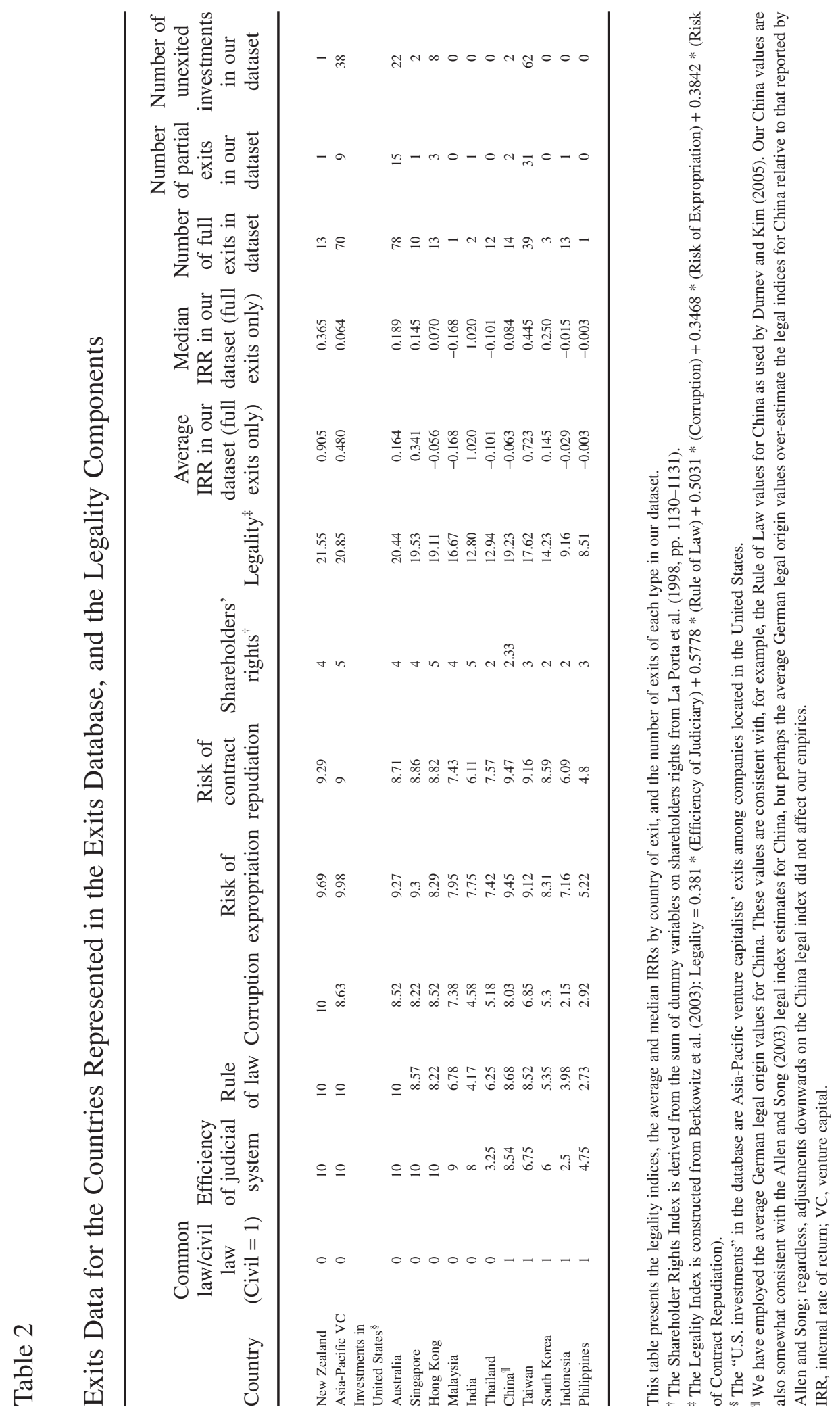




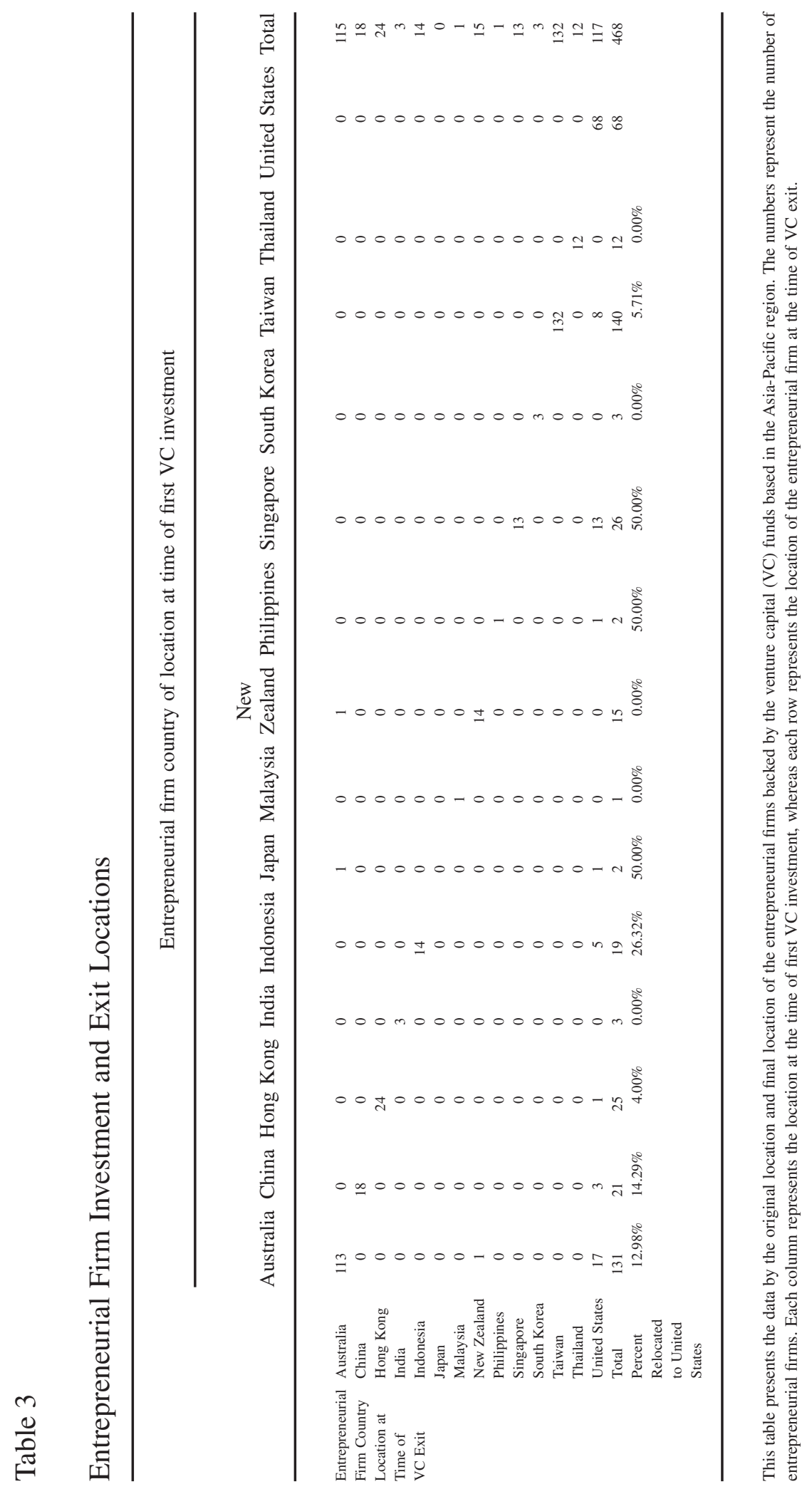


Figure 1

Histogram of Returns to Venture Investment by Relocation and Realization

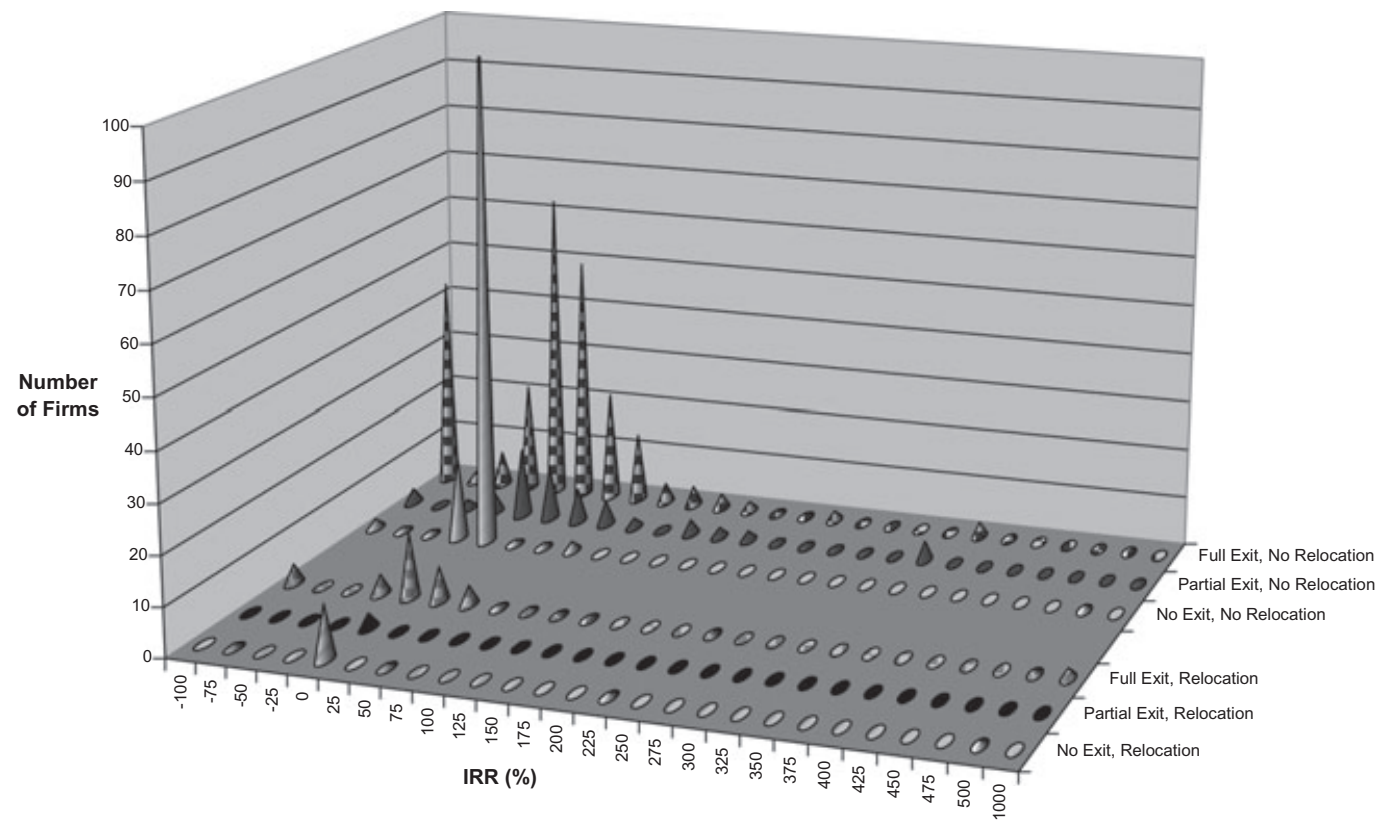

Figure 2

Venture Investment and Exit by Relocation and Date

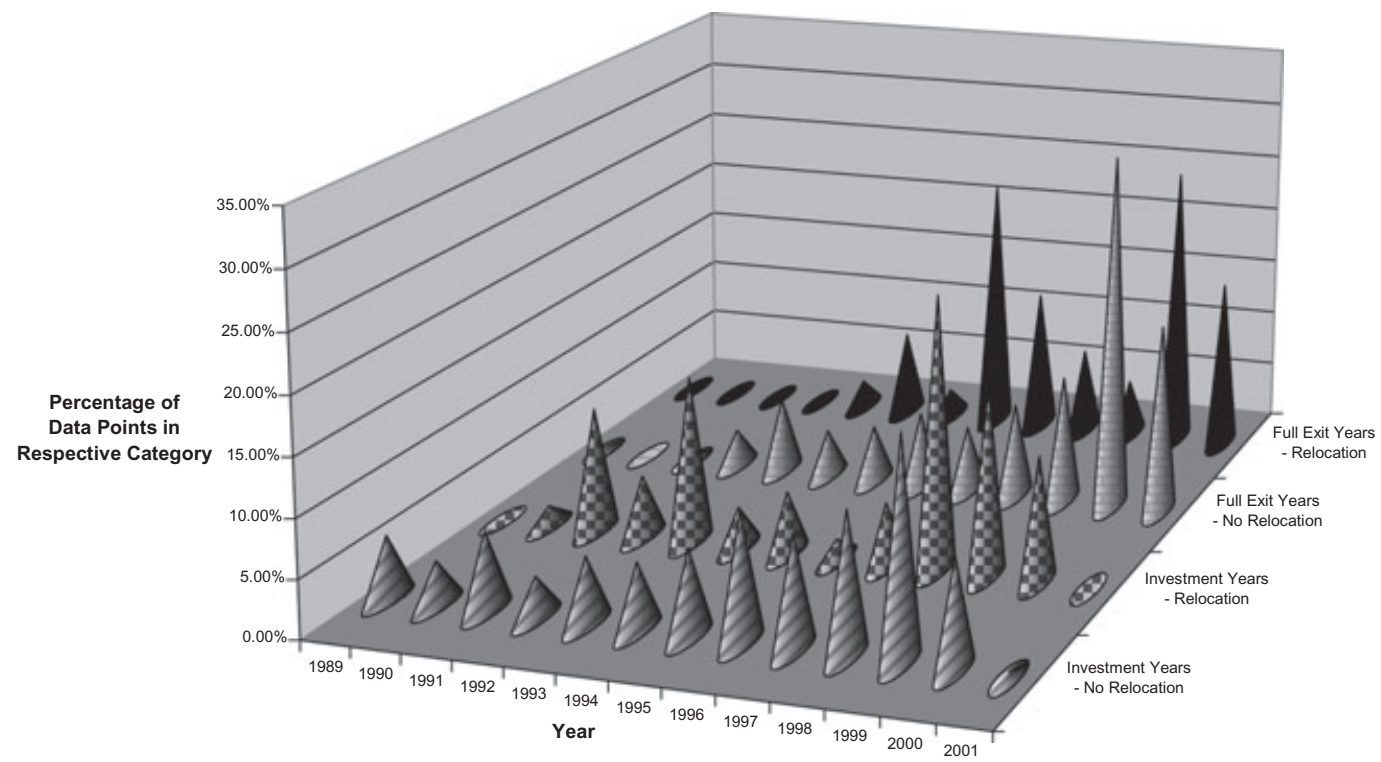


relocations observed were moves to the United States (the inclusion/exclusion of these three relocations was immaterial to our analyses and results, except where explicitly indicated). The table further shows that 68 investments (out of 468) were by Asia-Pacific funds in entrepreneurial firms already located in the United States at the time of investment. We compare these cross-border investments with the relocations in our empirical analysis.

A correlation matrix is provided in Table 4. Statistically significant values (at the $5 \%$ level) are underlined. A number of intuitive findings are observed with the simple correlations. For example, the data indicate that entrepreneurial firms situated in countries of lower Legality tend to not be in high-tech industries, which is in line with the notion that weaker protection of intellectual property rights deters high-tech investments. (The correlation between the legality index at country of exit and legality index at country of investment was 0.85 , and hence we do not report the correlations for both variables as the inferences drawn are apparent from just reporting the legality index of the country at exit. This strong correlation is not surprising. It is largely driven by the fact that values are largely the same for those investments that did not relocate. Since only a subset has in fact relocated to the United States, we inevitably obtain a large correlation between these two variables.) The difference in terms of stage of development (at first round of financing), however, is not significantly different relative to the legality index.

The legality index, GDP, and population are all higher for Asia-Pacific VC-backed firms that relocated to the United States, and for firms that were in the United States at the time of investment from an Asia-Pacific VC. Hence, the data provide apparent support for both Hypotheses 1 and 2. The next section considers in more detail the relative importance of these variables and competing hypotheses in a multivariate setting.

Interestingly, investments by Asia-Pacific funds in companies based in the United States at the time of investment performed much worse than investments that were initially based in the Asia-Pacific region and then subsequently relocated to the United States. The average (median) fully realized IRR for a company that moved to the United States from the Asia-Pacific region was $112.4 \%$ (12.9\%), compared with an average (median) IRR of $-15.1 \%(-0.5 \%)$ for investments in companies already based in the United States at the time of an Asia-Pacific investment. Excluding investments in firms that were initially based in the United States, and investments in firms that were moved to the United States, the average (median) return on investment was $27.8 \%(20.1 \%)$. This evidence is highly suggestive of problems of adverse selection for Asia-Pacific VCs financing U.S.-based companies at the time of initial investment. The data are consistent with the view that higher quality entrepreneurial firms obtain financing from U.S.-based venture capitalists at the time of initial investment (based on evidence from U.S.-only studies, such as the seminal work in Gompers and Lerner, 1999), and lower quality entrepreneurs based in the United States end up being financed by overseas Asia-Pacific investors (this interpretation is somewhat consistent with the theory and evidence provided by Hsu, 2004). Note also that means differ substantially from medians, consistent with the general finding that IRRs of VC investments are not symmetrically distributed around the mean. Rather, average returns are strongly affected by extreme values. Therefore, we also report medians throughout the discussion.

We note that virtually all of the relocations were partial in the sense that the company maintained some form of production base in their country of origin; that is, only one of the companies moved their production facilities altogether. Further, of all the relocations, only 16 companies moved their head office. Average (median) fully 


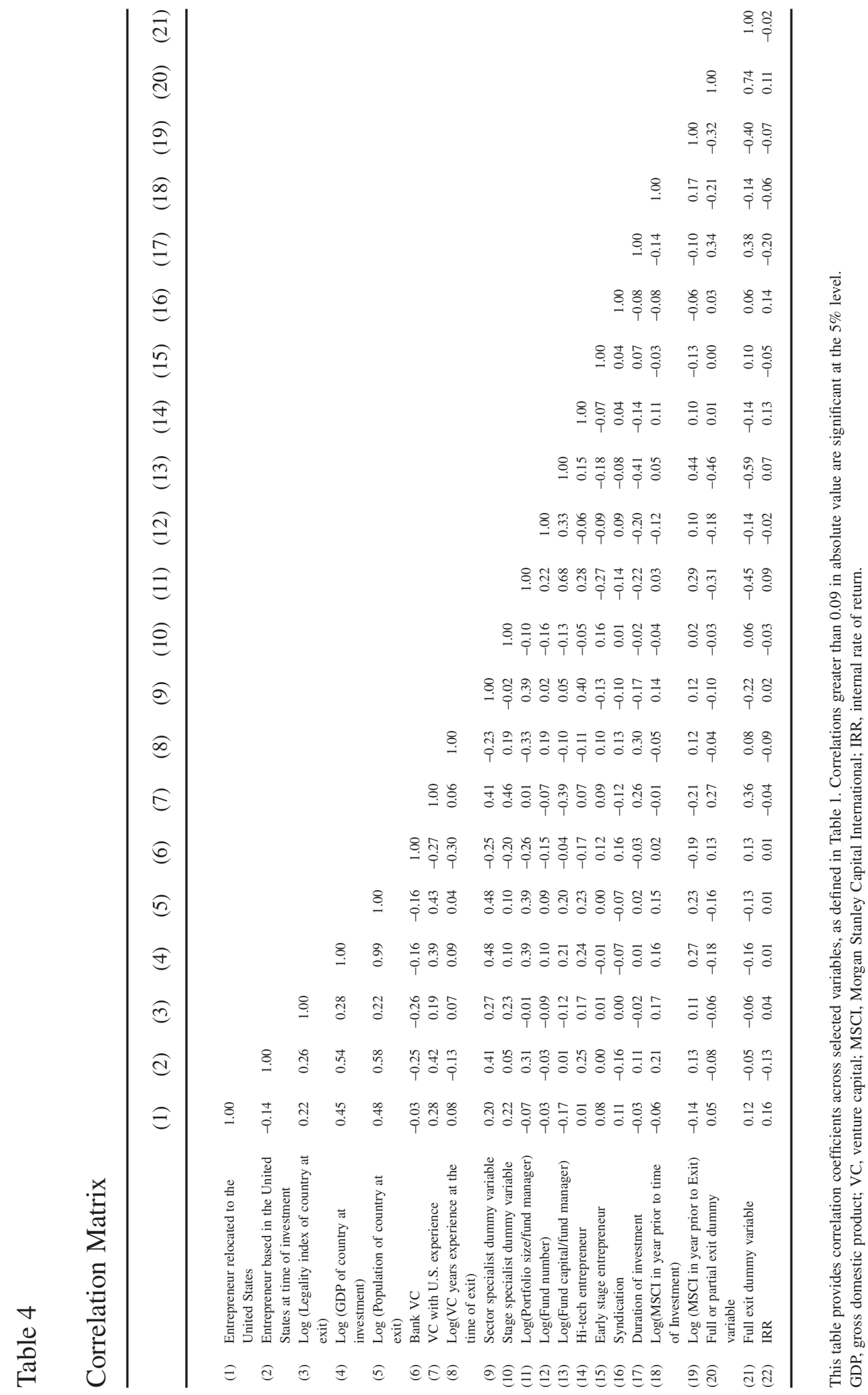


realized IRRs for companies that moved their head office were $259.2 \%$ (69.6\%) which is greater than the averages (medians) reported above for all moves, thereby indicating that a head office move was better for those companies. In the ensuing empirical analysis, we do not distinguish between head office moves and moves of production facilities since the limited number of such moves makes such distinctions immaterial or intractable in the multivariate analysis. As well, different variables for branch office moves used gave rise to the same qualitative inferences, and hence we do not report separate variables. Regardless, note that a creation of a branch office without moving the head office is consistent with the company's desire to access better laws in the new country (Hypothesis 1) and closer to a potentially larger customer base (Hypothesis 2). By relocating or establishing a legal presence in the new market, the company is still able to take advantage of locational advantages such as stronger local laws and regulations. This includes, but is not limited to, enforcement of contractual rights and securities laws, consistent with Hypothesis 1 . As well, a partial move still enables customers to be proximate with vendors, consistent with Hypothesis 2.

Various VC-specific factors are correlated with relocation and cross-border investment. For example, both relocation and cross-border investment are more common among VC funds that have U.S. experience, but cross-border investment is negatively associated with VC years of experience. VC funds that are specialized in certain industry sectors or stages of entrepreneurial firm development tend to be more likely to relocate their investee firms to the United States and invest cross-border in the U.S.-based firms. Syndication (across unrelated funds and not co-investment by companion funds) is associated with a greater frequency of relocations to the United States, which is suggestive of benefits to networking in syndication to facilitate a relocation (see also Lockett \& Wright, 1999, 2001; Wright \& Lockett, 2003). Syndication is less common for entrepreneurs based in the United States at the time of first investment.

The correlations in Table 4 provide suggestive but not conclusive evidence. The correlations also provide guidance as to which variables are potentially problematic for reasons of collinearity in the multivariate empirical analyses. We turn now to a more formal testing of our hypotheses using multivariate analysis.

\section{Multivariate Analyses}

\section{Project Selection}

As a precursor to the direct tests of Hypotheses 1 and 2, we first assessed the importance of legal and economic conditions at the time of first investment in relation to the probability of early stage and high-technology companies receiving capital from venture capitalists (prior to an actual relocation of the company) (the corollaries of the two hypotheses). We model the probability of the decision to invest using both binary and ordered logit models. The general form of these models is as follows:

Prob $($ Early stage/High tech $)=\mathrm{f}$ (Institutional Factors, Fund and Transaction Characteristics, Market Conditions)

This model relates the venture capitalists' project selection to our primary variables of interest—-legal systems and fund characteristics — while controlling for market conditions at the time of the investment. This provides a preliminary look at the data to illustrate how investment decisions by venture capitalists vary across countries. We report alternative specifications to show robustness to different control variables. 
Our analysis of investment choice is summarized in Table 5. We examine the determinants of project selection by Asia-Pacific venture capitalists in terms of riskier hightech companies and early stage of entrepreneurial firm development in the first round of investment. The dependent variable in Models (1)-(3) is equal to 1 for a high-tech investment and 0 otherwise. The dependent variable in Models (4)-(6) is equal to 1 for an early stage investment and 0 otherwise. The dependent variable in Models (7)-(9) is equal to 2 for an early stage and high-tech investment, 1 for an early stage or high-tech investment, and 0 if the investment was neither in an early stage company nor a high-tech company. An ordered logit model is used to estimate Models (7)-(9). These choices of investment dependent variables are explained by legal conditions in the country of investee location, fund characteristics, and by market conditions. The specific right-handside variables are listed in Table 5, and defined in Table 1. We use a logarithmic specification to account for a diminishing effect of an improvement in law quality on risky investment decisions, as well as a diminishing effect of a greater number of year's experience, and fund capital per manager (the latter variable is used as a proxy for experience and reputation). For each of the three different dependent variables, we present three of the same set of alternative right-hand-side variables in order to show robustness.

The data indicate that a country's Legality index is statistically related to the probability of financing a high-tech company (at the $1 \%$ level of significance in Models [1]-[3]). This is consistent with the corollary to Hypothesis 1. In terms of economic significance, a change in the Legality index from 19 to 20 (approximately the change associated with a move from Hong Kong to Australia) increases the probability that a high-tech firm will be financed by approximately $0.8 \%$, while a change in Legality from 8 to 9 (approximately the change associated with a move from The Philippines to Indonesia) increases the probability that a high-tech firm will be financed by approximately $1.9 \%$.

Despite the strong economic and statistical impact of international differences in law quality on the probability of financing a high-tech company, it is noteworthy that we do not find evidence of international differences in legality impacting the financing of earlier stage companies (Models [4]-[6]). One possible explanation for this result is that stage of development definitions differ across countries, and our measure of early stage is preprofit (Table 1). More precise definitions were not ascertainable across the multitude of countries in our sample, due to the fact that there are international differences in the meaning of the terms "seed," "start-up," and "expansion" financing used in practice by venture capitalists. Nevertheless, there is some evidence, albeit only significant at the $10 \%$ level in Models (5) and (6) and insignificant in Model (4), that earlier stage companies are more likely to be financed in higher GDP countries (consistent with the corollary to Hypothesis 2 discussed in section 2 previously).

Some of the control variables for fund characteristics are statistically significant in Table 5. Captive VC firms are less likely to finance high-tech companies, but more likely to finance early stage companies. Venture capitalists with a self-proclaimed industry sector specialization are more likely to have such a specialization in a high-tech sector, while funds with a self-proclaimed stage focus are more likely to have such a focus in the earlier stages of entrepreneurial firm development. Funds with more capital under management per manager (as a proxy for experience) are also more likely to have a focus in the high-tech sectors. Finally, there is weak evidence that better market conditions increase the probability of high-tech investment in Model (1); however, that effect is not robust to the inclusion of the control variables in the other models (although the year of investment dummy variables in Model [3] did indicate some statistically significant difference in different years surrounding the Internet bubble). 


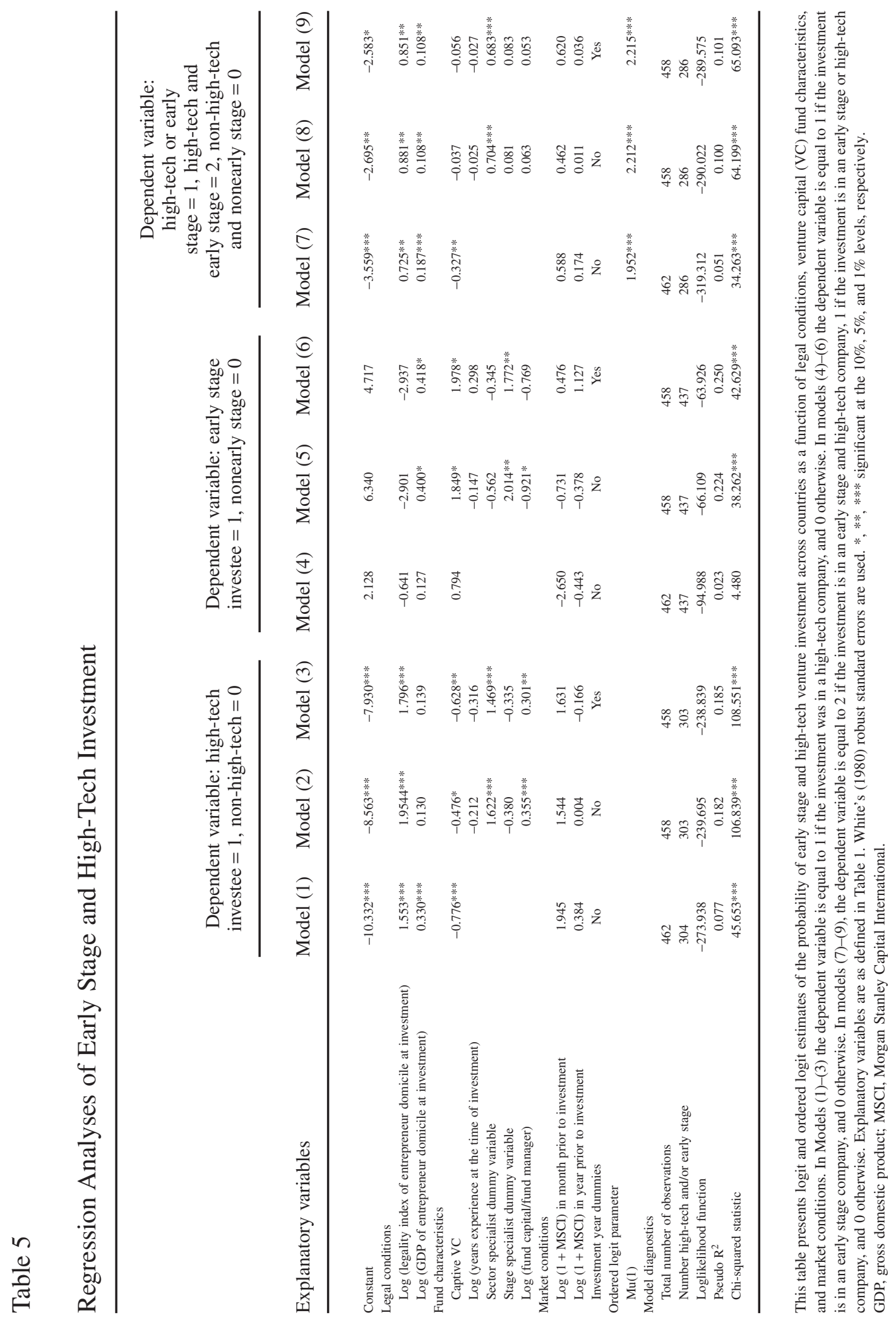




\section{Venture Capitalists Strategies to Relocate New Ventures and the Returns to Relocation}

In this subsection, we test the factors that give rise to venture capitalists relocating their investee firms, providing a direct test of Hypotheses 1 and 2. We also assess the impact of the relocation on rate of return of the investment (as measured in the IRR). We utilize bivariate Heckman correction models to account for sample selection corrections. It is important to consider the nonrandomness of the decision to move in ascertaining the impact of a move on the rate of return, as the decision to move is not a random event and hence standard ordinary least squares (OLS) estimates would be biased (Heckman, 1976, 1979). It is also important to assess fully exited investments and nonexited investments, as the decision to divest is likewise not a random event. Heckman corrections are used for the analysis of returns to relocation for the same reasons that Heckman developed the statistical selection methodology in the context of measuring wages in labor migration models. That is, we observe the returns associated with the relocated investee company, but we do not observe the return that the company would have received if it had not relocated. It may be the case (and it is in fact expected to be the case) that a nonrandom process drives the selection of companies for relocation. If so, the analysis of the distribution of returns to relocation needs to account for which companies were selected for such relocation. The models therefore have the following general form:

Step A Model:

Prob (Move to US) $=\mathrm{f}$ (Institutional Factors, Fund Characteristics, Entrepreneur Characteristics, Market Conditions)

Step B Model:

Prob $($ Full Exit $)=\mathrm{f}($ Investment Duration, Market Conditions $)$

Step C Model (Heckman Correction Estimates of IRRs for the Subset of Moves to US):

$\mathrm{IRR}=\mathrm{f}$ (Fund Characteristics, Entrepreneur Characteristics, Market Conditions/ Move to US and Full Exit)

The first two steps of the model are jointly estimated. The first step regression sets the venture capitalists' decision to relocate as one (recall our data comprises relocated and nonrelocated investments). The second step regression controls for whether the equity relocation has been fully exited. Step 3 then examines the distribution of returns to the equity relocation on the subset of companies that actually relocated, accounting for the nonrandomness in the decision to relocate to the United States, and the full/partial exit decision. We also run ordinary least squares models on the IRR data of the subset of fully exited investments that relocated to the United States for comparison as an additional robustness check.

Note that $10.47 \%$ of firms moved to the United States in our sample (see Table 3). There were $57.69 \%$ of firms that had a full exit, $13.68 \%$ that had a partial exit, and $28.85 \%$ that did not have an exit. The average IRR was $36.25 \%$, and median IRR was $6.4 \%$. A total of 48 investments were a complete write-off ( $-100 \%$ IRR; see Figure 1 for the histogram of IRRs, and Table 2 for IRRs by country).

Table 6 examines the motivations for an Asia-Pacific fund to relocate the new ventures of an investee company to the United States, and the determinants of the returns associated with such relocations. The analysis of returns in Table 6 only considers returns associated with the companies that relocated, and not the returns for investee companies that did not relocate (Table 7, discussed in a subsection below, considers returns to those other investments). 


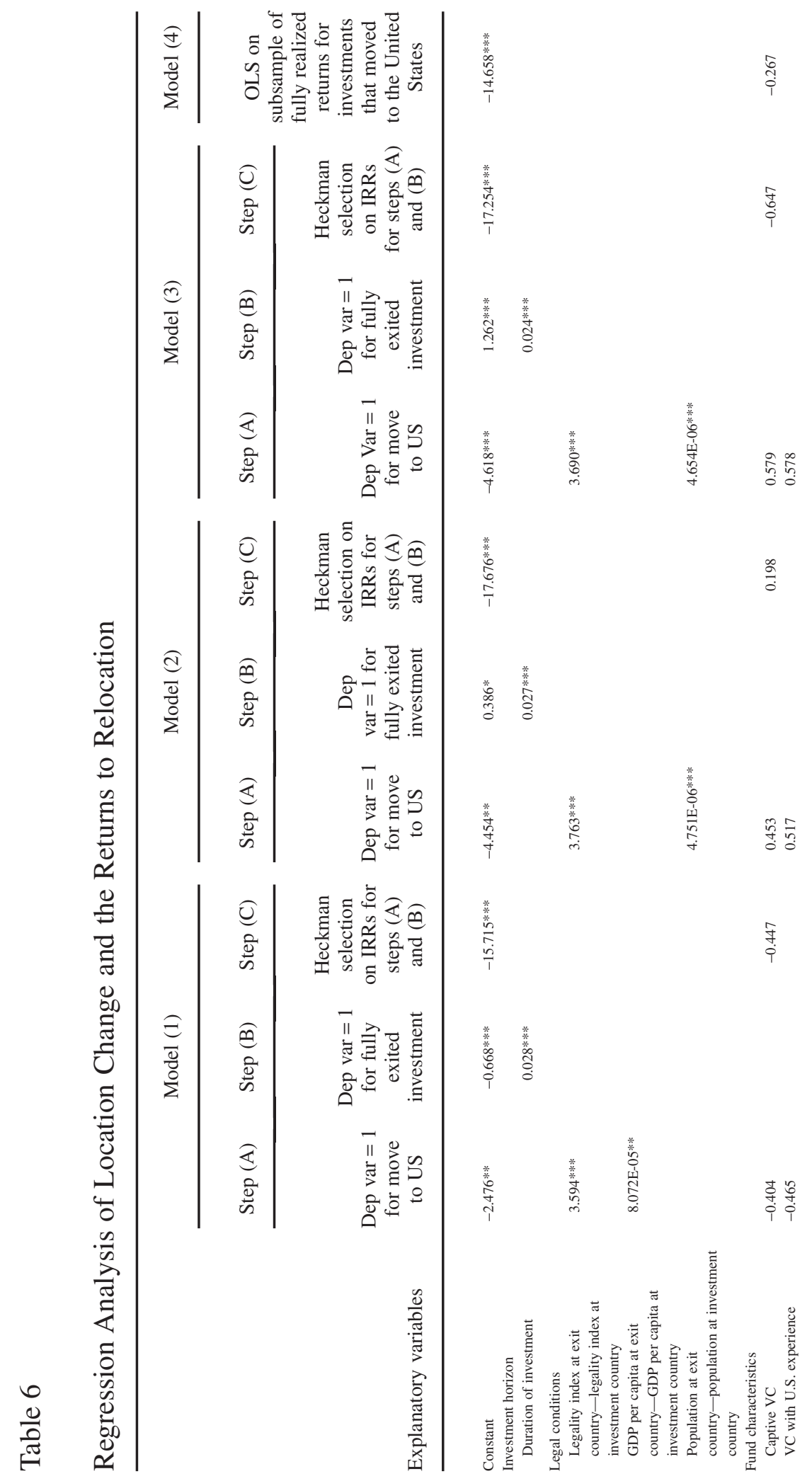




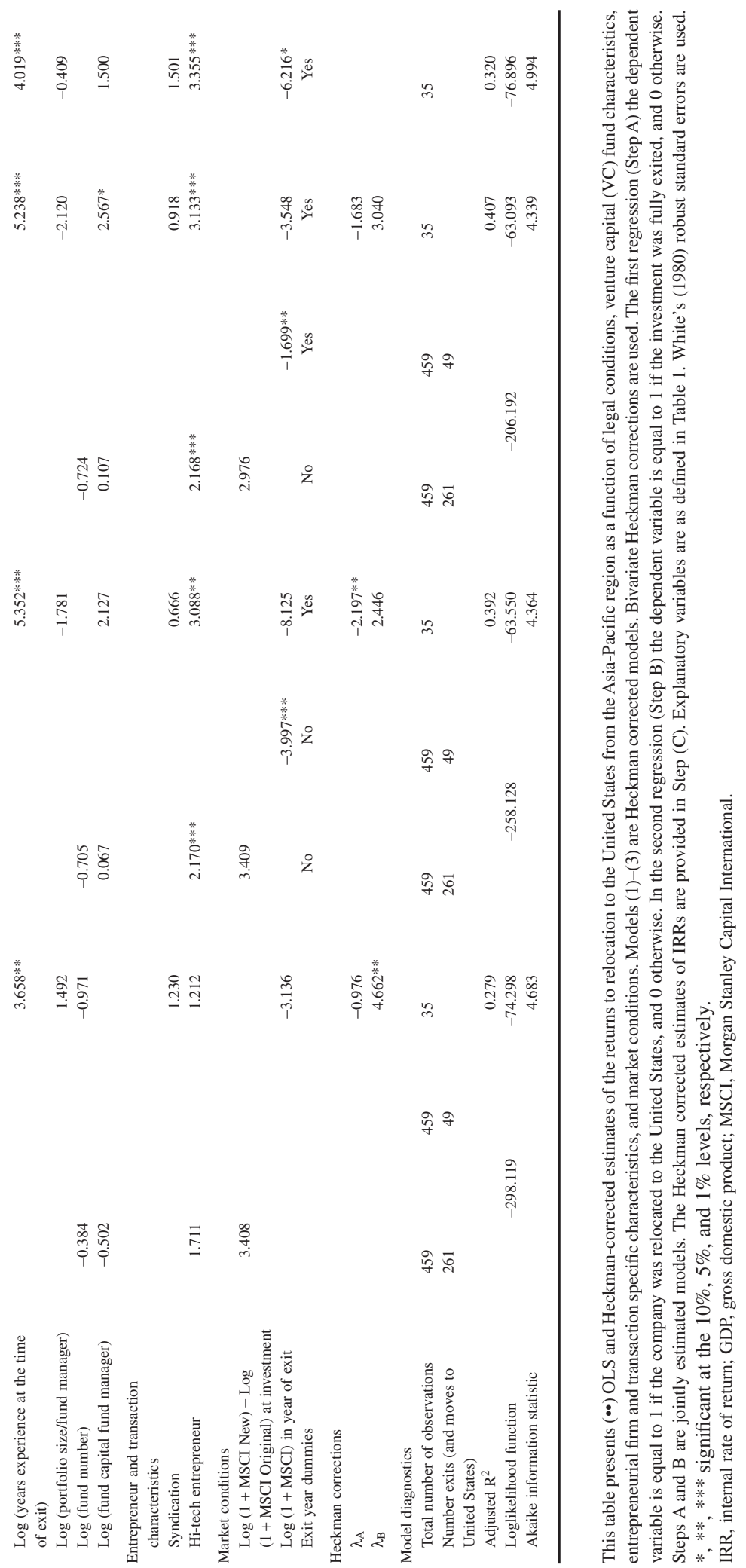




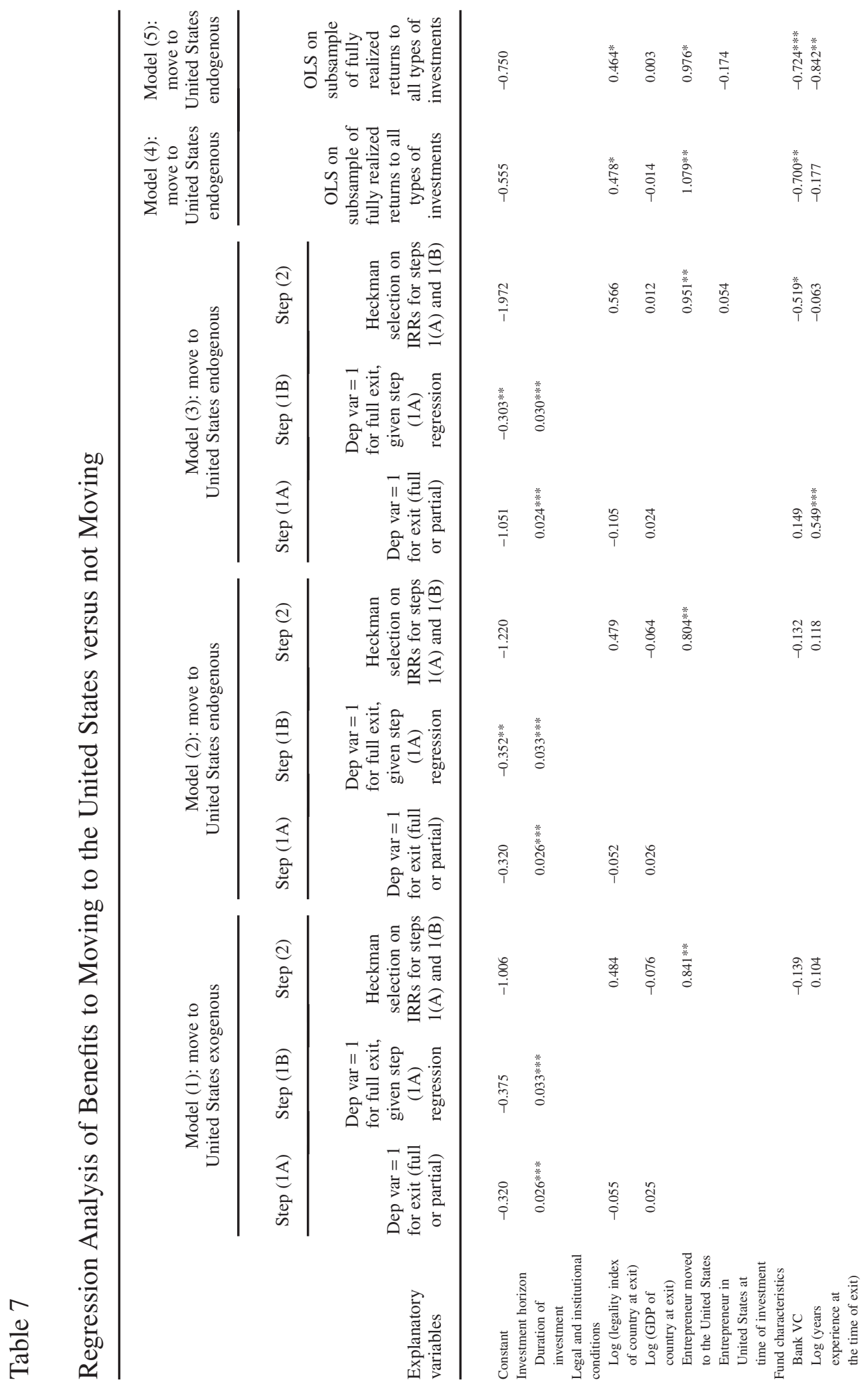




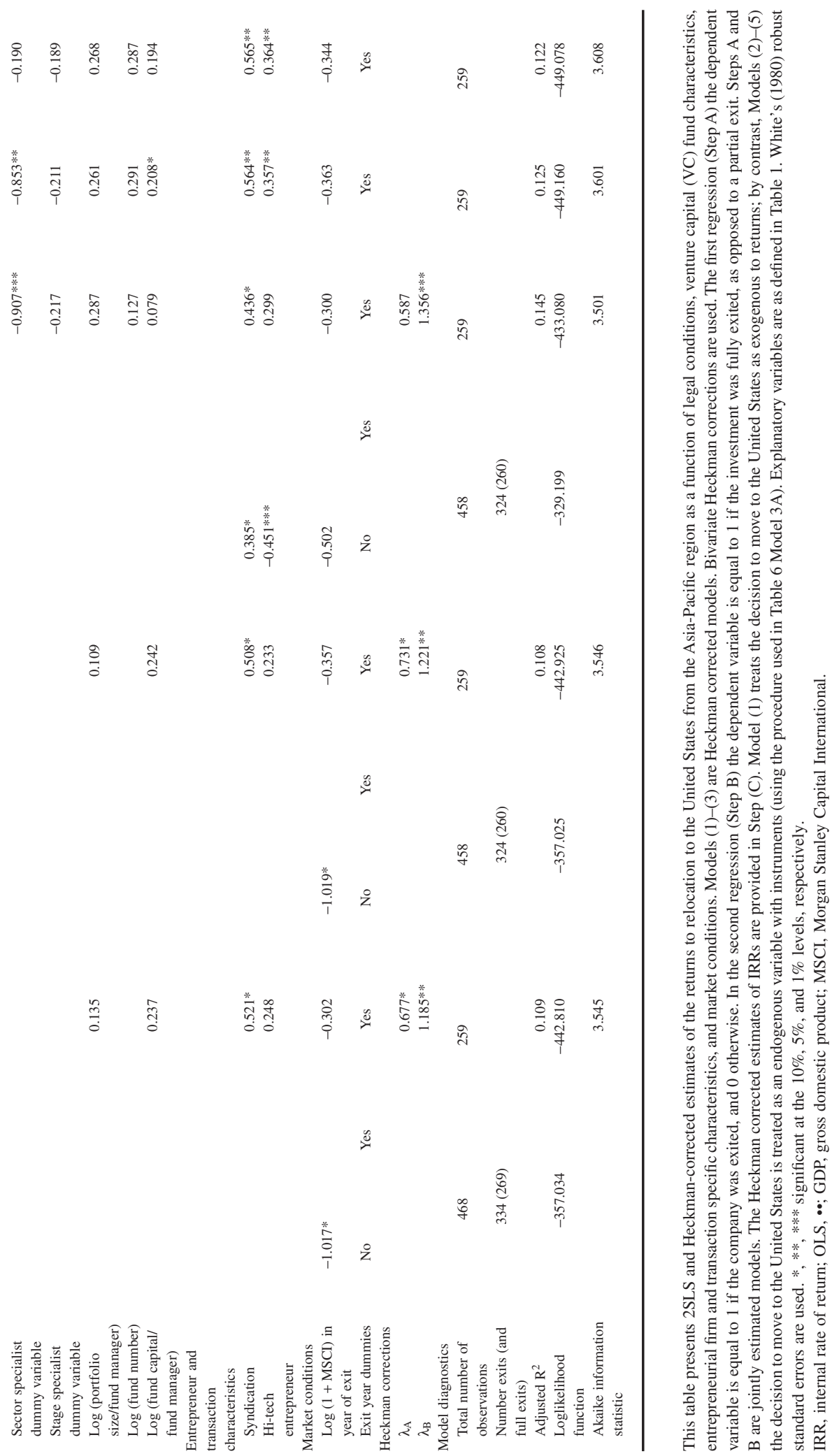


In Models (1)-(3), we use Heckman-corrected estimates of the returns to relocation as a function of legal conditions, fund characteristics, entrepreneur and transaction characteristics, and market conditions. The first step (Step A) estimates the probability of a move to the United States. As discussed, the Heckman correction is used to take into account the fact that the decision to relocate is a strategic decision. There is a second strategic decision that can impact the distribution of returns, for which a second step in the Heckman correction is used: full versus partial exit transactions (see subsection 3.2 and note 8 for definitions). Step B considers the probability for a full exit as a function of the duration of investment and market conditions in the year of exit. Step C gives the Heckman-corrected estimates of IRRs, taking into account the nonrandomness associated with the relocation decision and the exit strategy in Steps A and B. Models (1) to (3) differ in the use of exit year dummies and other control variables.

Step A in Models (1)-(3) indicate that the decision to move to the United States is a function of the quality in the laws in the home country. In cases where the differences in the laws in the United States and the home country are more pronounced (i.e., when the law quality is worse in the original country), the investee company is more likely to be relocated to the United States. This is strong evidence in support of Hypothesis 1. This effect is statistically significant at the $1 \%$ level in each of Models (1)-(3). The economic significance indicates that, for example, a move to the United States has a $2.8 \%$ greater chance of originating from Singapore than it does from Australia. This shows strong support for Hypothesis 1: the worse the legal conditions in the initial country, the greater the likelihood of moving the investee to the United States prior to VC exit.

In order to assess Hypothesis 2, we consider GDP per capita in Model 1A and population in Models 2A and 3A. Consistent with Hypothesis 2, Model 1A indicates that companies located in countries with lower levels of GDP per capita are more likely to move to the United States, and this effect is significant at the 5\% level of significance. The economic significance is such that relocations to the United States are approximately $4.5 \%$ more likely to originate from countries with GDP per capita of USD 5,000 (such as the Philippines) relative to countries with GDP per capita of USD 30,000 (such as Australia). Step A in Models (2) and (3) further indicate that there is a greater chance of moving firms to the United States where there are greater differences in the population base, and this effect is statistically significant at the $1 \%$ level. This is consistent with Hypothesis 2 . The economic significance associated with population differences is such that, for example, relocations are $0.3 \%$ more likely to originate from a country with a population of 5 million (such as Singapore) than a country with a population of 20 million (such as Australia).

Overall, therefore, both legal conditions and customer base are important for decisions to relocate, as conjectured in Hypotheses 1 and 2. Also, it is noteworthy that high-tech firms are $7 \%$ more likely to be moved to the United States. This is consistent with the notion underlying Hypothesis 4 that high-tech firms exhibit greater information asymmetries, and hence it is worthwhile to relocate a high-tech firm prior to exit to minimize agency costs and information asymmetries faced by the new owners of the firm and hence maximize the sale value. The other control variables in the Step A regressions in Table 6 are not significant.

Note that we considered separate regressions (not reported but available upon request) to assess the separate impact of moving a head office versus a branch office. For instance, one might argue that a branch office is more likely to be established for reasons relating to market proximity (Hypothesis 2), whereas a head office relocation is associated with legal certainty (Hypothesis 1). However, it is unlikely that a firm would move head office without setting up a branch office first, and hence establishing a branch office could be motivated by legal reasons. In the data, the fact that there are only 16 head office moves 
is insufficient to assess this variable in the regressions. In regressions with the branch office variable, the impact of laws is positive and significant and the GDP variable is insignificant.

Step B in Models (1)-(3) indicate that full exits are more likely for times over which the duration of investment is longer, consistent with Cumming and MacIntosh (2003). Models (2) and (3) also indicate full exits are less likely when MSCI returns are higher in the year of exit, which indicates venture capitalists to want to cash out quicker when market conditions are weak. We do not include other controls for the determinants of full versus partial exits; the main reason is that the Heckman selection equations become sensitive to over-specification bias if there are too many variables that overlap across the regression equations (see e.g., Puhani, 2000, for a discussion).

Step C in Models (1)-(3) provide very strong evidence that the returns to corporate relocation are greatest for the more experienced fund managers, which is consistent with Hypothesis 3. As well, the results are consistent with various theoretical models of VC experience and value added (e.g, Casamatta, 2003; Chan, Siegel, \& Thakor, 1990). The economic significance of fund manager experience is very large; for example, returns to moving are approximately $5.4 \%$ higher for an increase in cumulative years of experience across all managers from 30 to 31 years. (The calculation is $\log (31)-\log$ (30) * 3.8, based on the more conservative estimated coefficient in Model (1) in Table 6. Alternative specifications of this variable included experience at the time of investment, and experience per fund manager, as presented in the summary statistics in Table 4. Such alternatives did not materially affect the results and are available upon request.) This evidence is consistent in spirit to results showing persistence in private equity returns among U.S. VC managers (Kaplan \& Schoar, 2005). The evidence further indicates that the other variables are generally insignificant, with the exception of the hightech variable in Models (2) and (3).

Model (4) in Table 6 is presented primarily for comparison to show simple OLS estimates of returns on the subsample of the relocated companies that have been fully exited. It is consistent with the importance of investor experience in driving the returns to relocation. It also shows a positive effect on returns for relocating high-tech companies.

In summary, differences in legal conditions and market opportunities between the country of origin and country of exit have a significant impact on the likelihood of moving to the United States. The greater the difference in Legality, the more likely is the relocation (Step A in Models [1]-[3]). High-tech companies are also more likely to move. Importantly, the regressions show a large, positive, and statistically significant effect of fund manager experience on returns for companies that relocated.

\section{Do Cross-border Investments Pay Off? A Comparison of VC Investment Returns}

In the prior subsection, we examined the factors that lead to a decision to relocate an investee firm to the United States, and the returns associated with the subset of firms that had relocated. In this subsection, we analyze the returns to all investee firms, regardless of whether or not such firms were relocated to the United States. We model the success of the venture capitalists' cross-border equity investments, with comparison to firms that did not relocate. Again, we adopt bivariate Heckman correction models in the following forms:

Step A Model:

Prob $($ Exit Has Occurred $)=\mathrm{f}($ Investment Duration $)$ 
Step B Model:

Prob (Full Exit/Exit Has Occurred) = f (Institutional Factors, Fund Characteristics, Entrepreneur Characteristics, Market Conditions)

Step C Model (Heckman Corrected Estimates of IRRs for All Investments):

$\mathrm{IRR}=\mathrm{f}$ (Institutional Factors, Moves to the US, Fund Characteristics, Entrepreneur Characteristics, Market Conditions/Exited Investment and Full Exit)

The first step regression controls for randomness of the exit event. This is important, as it may be the case that the exited investments have properties which are systematically different from the nonexited investments (Cochrane, 2005; Nikoskelainen \& Wright, 2007). This is important, as the data may have a distortion toward the realizations of better-performing investments. The second step controls for the fact that the fully realized exits may have properties that are distinct from the partially realized exits. The complete returns are only observed in full for the fully realized exits. The second step also accounts for the nonrandomness in the exit decision in the spirit of Heckman $(1976,1979)$. The first two steps (labeled $1 \mathrm{~A}$ and $1 \mathrm{~B}$ in Table 7) involve a joint estimation. The third step estimates the returns taking into account the nonrandomness in the exit decision and the full/partial exit decision using the Heckman correction. Moves to the United States are treated as exogenous and endogenous in different specifications of the model to check for robustness. We also run ordinary least squares models on the returns data for the complete set of firms that did and did not relocate for comparison and robustness checks in Models (4) and (5) in Table 7. Models (1)-(5) in Table 7 further differ in regard to the treatment of the relocation to the United States either as exogenous or endogenous. In Model (1), the decision is treated as exogenous, and in Models (2)-(5), the decision to move to the United States is treated as an endogenous variable with instruments (using the procedure used in Table 6 Model 3A, described previously).

The Step (1A) estimates in Models (1)-(3) in Table 7 indicate (as expected) that the longer a venture capitalist has been invested in a company, the greater the probability that such investment has been exited. The Step (1B) estimates in Models (1)-(3) indicate that full exits are more likely the longer the duration of investment. This is also expected, since the motivation underlying a partial exit is to certify the quality of an investment (Cumming $\&$ MacIntosh, 2003). The certification rationale is diminished the longer the duration of investment, since longer duration itself is a mechanism for certifying the quality of the investment (Megginson \& Weiss, 1991). Similarly, Step (1B) in Models (2) and (3) indicating full exits are more likely the greater experience for the venture capitalist. This is also expected, since the need to certify the quality of the investment via a partial exit is diminished when the venture capitalist's reputation itself is sufficient to certify the quality of the investment. As pointed out in the previous subsection, we limit the number of controls for the determinants of exits versus nonexits, and for full versus partial exits, in the Heckman selection equations to avoid a potential over-specification bias. Other specifications considered did not materially impact the results (alternative specifications are available upon request).

The factors that affect the returns to investment are illustrated in the Step 2 regressions in Models (1)-(3), and in the Model (4) and (5) regressions. First, note that the returns are higher for investee firms that relocated to the United States (relative to investing in companies based in the United States at the time of investment and relative to domestic investments not relocated to the United States). This result is statistically significant and economically large, and the statistical significance is robust to the potential endogeneity of this variable (Models [2]-[5], which account for the fact that better companies are moved to the United States). Moving the company to the United States in fact facilitates 
an increase in returns by approximately $80 \%$ (based on the most conservative estimate of this variable in Model 2) to $108 \%$ (based on the least conservative estimate of this variable in Model 4). In short, the data indicate large, significant benefits associated with moving a company to the United States in terms of capturing higher capital gains. The direct costs of moving companies to the United States, however, are not reflected in the returns calculations (i.e., the costs are not subtracted from the capital gains). Hence, these estimated returns overstate the benefit to the VC fund.

It is noteworthy that the market returns are generally insignificant in each of the returns regressions. This evidence is suggestive that Asia-Pacific venture capitalists are on average less skilled at timing their exits relative to their United States counterparts (see Gompers \& Lerner, 1999; see also Cochrane, 2005, for the view that market conditions are a primary driver of $\mathrm{VC}$ returns). Nevertheless, note that all the regressions do include numerous dummy variable controls for the years of exit (consistent with Gompers \& Lerner), and many of those dummy variables are statistically significant (but not explicitly reported for reasons of conciseness in presentation).

A number of other control variables in the returns regressions are significant, although not all are robust to the different econometric methods employed. There is evidence in Models (4) and (5) that captive venture capitalists earn lower returns (consistent with Hypothesis 3, as well as prior U.S. studies; see Gompers \& Lerner, 1999); however, that result is not robust to the statistical selection effect regression in Models (1)-(3). Models (3) and (4) indicate that sector specialization among some funds (i.e., a lack of diversification across different industries) was associated with lower returns. Models (4) and (5) indicate high-tech firms generated higher returns in the sample. Specific industry controls did not materially change the results of interest; therefore, we used a more parsimonious specification with the high-tech dummy variable only.

All five models in Table 7 indicate syndication is associated with higher returns, suggesting a value-added role of syndication (see, e.g., Wright \& Lockett, 2003) (see also Hypothesis 3). In Table 6 for the subsample of relocations, the impact of syndication on returns was statistically insignificant, while in Table 7 all of the estimates indicate a positive role of syndication. Of the relocations to the United States, $26.53 \%$ were syndicated, and the correlation between syndication and IRR is 0.30 for the subsample that relocated. Of the nonrelocations to the United States, $15.04 \%$ of the investments were syndicated at the correlation between syndication and IRR is 0.04 . Hence, the best explanation for the insignificance of the syndication variable in Table 6 (unlike Table 7) is that it is correlated with the other variables and lacks additional explanatory power with the smaller number of observations in the reduced sample in Table 6. As well, we acknowledge that the syndication variable is potentially endogenous (i.e., the decision to syndicate may depend on entrepreneurial firm quality). We considered potential instruments (although were limited in the availability of suitable instruments that were not correlated with returns), and did not find major differences with alternative procedures. Including/excluding this variable did not impact any of the other results of interest (other specifications are available upon request). Further research with more specific data (and perhaps case studies) may shed light on this issue. Concluding remarks and additional suggestions for other new directions for further research are provided in the next section.

\section{Limitations, Future Research, and Practical Implications}

This paper developed four new hypotheses pertaining to international relocation of VC-backed companies. These hypotheses centered on institutional factors (Hypothesis 1), 
market factors (Hypothesis 2), venture capitalist value-added factors (Hypothesis 3), and portfolio factors (Hypothesis 4).

In our empirical tests, we considered a variety of variables within a dataset involving $53 \mathrm{VC}$ funds involving 468 investee companies and 12 countries in the Asia-Pacific region. In this section, we first describe some of the other variables that we considered but did not explicitly report in the empirical tables discussed previously. Thereafter, we discuss future research and practical implications.

In our empirical analyses, we considered a variety of other variables not reported in the tables. For instance, we tested local economic conditions with the use variables for GDP and GDP per capita. We considered other variables, such as the supply of VC and the number of IPOs in the country; however, these alternative variables for market quality are all highly correlated with GDP and GDP per capita and as such it is difficult to incorporate those variables simultaneously due to collinearity problems. As well, we considered interaction terms with legality indices and industry variables (among other interaction terms), but do not explicitly report those variables as they generally turned out to be statistically insignificant. It is possible that larger datasets in the future might reveal more definitive patterns in respect to interaction effects. Tax is also relevant for VC (Kanniainen \& Keuschnigg, 2003, 2004; Keuschnigg, 2003, 2004b; Keuschnigg \& Nielsen, 2001, 2003a, 2003b, 2004; Poterba, 1989a, 1989b). In this paper, we did not find evidence of tax driving relocations; however, there may be unobserved tax strategies associated with relocation which we could not observe in our data and as such further research is warranted. As well, the size of VC markets may further affect the decision to relocate. However, in our dataset, we did not find a material effect. For instance, in Table 6 Model 1 Step A, when we include a variable for the size of the VC market in different countries, the coefficient is -0.008 and the t-statistic is statistically insignificant with a value of -0.195 ; the other coefficients reported in Table 6 are unaffected. Finally, VC Funds with branch offices in different countries may influence relocation. Unfortunately, our dataset does not comprise funds with branch offices and we believe that further research with other types of funds might shed light on this issue.

It is important to acknowledge that technology adoption rates in a country may affect the supply of feasible investments and the demand for such products. In Table 5, using data from the World Bank (World Development Indicators database) on a countryyear basis for Internet adoption (number of Internet users per 100 people), high-tech exports (high-technology exports as percentage of manufactured exports), and phone usage (fixed line and mobile phone subscribers per 100 people), we found mixed evidence that these additional variables impacted the decision to invest in high-tech companies. In particular, Internet adoption is significantly positively related to the probability of a high-tech investment, but not the variable for high-tech exports and/or the variable for phone usage. The Internet variable mitigates the role of the legal environment in Table 5, largely because Internet adoption is significantly correlated with the legal environment (the correlation is 0.46). It is likely that legal conditions have an important role in facilitating the adoption of technological improvements in a country in the first place (consistent with La Porta et al., 1998, among others), which would explain this high correlation.

Further, technology adoption rates may give rise to an additional indication of the potential market products in a country. Again, using data from the World Bank (World Development Indicators database) on a country-year basis for Internet adoption, high-tech exports, and phone usage, we did not find these variables had any significant impact on the relocation decision. For instance, in Table 6 Model 1 Step A, when we include a variable for Internet adoption (phone) (high-tech exports) in different countries, the coefficient is 
$0.015(0.053)(0.004)$ and the t-statistic is statistically insignificant with a value of 0.441 (1.228) (0.706); the other coefficients reported in Table 6 are unaffected.

Overall, given these robustness checks, we believe our empirical measures provide strong support for each of the four hypotheses developed in this paper. In effect, we may conclude from the theory and evidence a number of new findings that contribute to the VC literature. The analysis further provides several practical implications of corporate relocation and thus incentives that govern transnational entrepreneurs. First, legal conditions are important for VC-backed companies and to the growth of a VC market. With the help of venture capitalists, entrepreneurs are more likely to move promising companies to markets with a stronger legal environment in order to facilitate the successful exit of investors. Second, international relocations facilitate locational advantages for the entrepreneurial investee firms in terms of being closer to consumers. Third, entrepreneurs backed by more experienced venture capitalists are more likely to experience greater success with their international relocations. Entrepreneurs in emerging countries therefore have a pronounced incentive to be backed by an experienced venture capitalist that is able to facilitate successful cross-border relocation. Finally, the characteristics of the entrepreneurial firm itself are important for driving the need for and success of the relocation. Earlier stage and high-tech firms are more feasibly relocated and more likely to benefit from international relocation. These are likely benefits of relocation for entrepreneurs. On the cost side, relocation may require from entrepreneurs greater flexibility and to operate in jurisdictions that are substantially different from their home country. It may further force entrepreneurs to favor specific investors who may facilitate a transnational approach, sometimes perhaps at the expense of other investors that may bring other benefits. More specifically, these investors may be needed in specific stages of development, making otherwise cross-border relocation more difficult in follow-up stages. Here we have identified international VC firms with strong experience as such investors.

\section{Concluding Remarks and Policy Implications}

VC investing involves identifying and financing high-risk entrepreneurial firms in conditions of technical uncertainty, information asymmetries, and rapidly changing market conditions. One feature of the increasing globalization of the VC industry is the decision by venture capitalists to relocate their investments to jurisdictions where shareholder rights are protected, liquidity is improved, and factor and product markets are more favorable. This paper provides the first empirical analysis of corporate relocations by private VC-backed companies. Based on data from 468 private companies that were financed by 53 venture capitalists based in 12 Asia-Pacific countries, we reported 49 relocations to the United States from Asia-Pacific countries after the companies were financed by an Asia-Pacific fund, and 68 companies already based in the United States at the time they were financed by an Asia-Pacific fund. We further reported that relocations within the Asia-Pacific region are extremely rare in the data (there were 3 in total; 2 to Australia and 1 to New Zealand).

Two of our main hypotheses were that international differences in both legal protections and market opportunities impact a venture capitalist's decision to invest in riskier industries and relocate those investments to the United States prior to exit. We found empirical support for both hypotheses: differences in law quality as well as market opportunities (proxied by GDP and population) were important in explaining the types of firms that received initial financing and the ways in which VCs relocated their investments to the United States. Further, we showed that among the companies that relocated to the 
United States, more experienced Asia-Pacific venture capitalists enjoyed much higher returns. Comparing the returns to relocation with the returns to not relocating, the multivariate tests and controls for selection effects and endogeneity indicated corporate relocations to the United States facilitated higher returns relative to staying in the country of origin.

It is noteworthy that the data indicated that relocations to the United States yielded much greater returns to Asia-Pacific venture capitalists than investing in companies already based in the United States at the time of investment. This evidence indicates significant adverse selection problems associated with cross-border investment at the time of initial investment, such that geographic distance inhibits project selection and due diligence.

The relocation of VC-backed companies has potentially important policy implications. VC in the Asia-Pacific region comprise a much smaller proportion of GDP relative to more developed countries. For example, early stage VC investments were $0.14 \%$ of GDP in the United States, and $0.2 \%$ of GDP in Australia and New Zealand; expansion stage investments were $0.3 \%$ of GDP in the United States, and $0.08 \%$ of GDP in Australia and New Zealand; total private equity (including buyouts) amounted to $0.63 \%$ of GDP in the United States and $0.14 \%$ of GDP in Australia and $0.12 \%$ of GDP in New Zealand (Cumming \& Johan, 2009, Ch. 1). It has been documented (Gompers et al., 2005) that successful companies that were once venture backed thereafter facilitate "entrepreneurial spawning" of new entrepreneurial ventures, thereby enhancing the overall size of a VC market and entrepreneurial climate in a country. Relocations diminish the spawning potential of successful VC-backed companies and have important policy implications given that any spawning will not be captured by the country in which the firm was established or financed (see also Keuschnigg, 2004a). Further theoretical and empirical research could explore in more detail the interaction between international business activities and VC-backed growth in emerging and developed countries.

\section{REFERENCES}

Albuquerque, R., Loayza, N., \& Servén, L. (2005). World market integration through the lens of foreign direct investors. Journal of International Economics, 66, 267-295.

Allen, F. \& Song, W.L. (2003). Venture capital and corporate governance. In P.K. Cornelius \& B. Kogut (Eds.), Corporate governance and capital flows in a global economy (pp. 133-176). New York: Oxford University Press.

Andersson, S. (2004). Internationalization in different industrial contexts. Journal of Business Venturing, 19, $851-875$.

Baker, T., Gedajlovic, E., \& Lubatkin, M. (2005). A framework for comparing entrepreneurship processes across nations. Journal of International Business Studies, 36, 492-504.

Batjargal, B. (2007). Network triads: Transitivity, referral and venture capital decisions in China and Russia. Journal of International Business Studies, 38, 998-1012.

Benos, E. \& Weisbach, M. (2004). Private benefits and cross-listing in the United States. Emerging Markets Review, 5, 217-240.

Berkowitz, D., Pistor, K., \& Richard, J.F. (2003). Economic development, legality, and the transplant effect. European Economic Review, 47, 165-195. 
Bowen, H. \& De Clercq, D. (2008). Institutional context and the allocation of entrepreneurial effort. Journal of International Business Studies, 39, 747-767.

Buckley, P.J., Clegg, L.J., Cross, A.R., Liu, X., Voss, H., \& Zheng, P. (2007). The determinants of Chinese outward foreign direct investment. Journal of International Business Studies, 38, 499-518.

Buckley, P.J. \& Hashai, N. (2004). A global system view of firm boundaries. Journal of International Business Studies, 35, 33-45.

Casamatta, C. (2003). Financing and advising: Optimal financial contracts with venture capitalists. Journal of Finance, 58, 2059-2086.

Chan, S.H., Gau, G.W., \& Wang, K. (1995). Stock market reaction to capital investment decisions: Evidence from business relocations. Journal of Financial and Quantitative Analysis, 30, 81-100.

Chan, Y.-S., Siegel, D.R., \& Thakor, A.V. (1990). Learning, corporate control and performance requirements in venture capital contracts. International Economic Review, 31, 365-382.

Claessens, S., Djankov, S., \& Lang, L. (2000). The separation of ownership and control in East Asian corporations. Journal of Financial Economics, 58, 81-112.

Cochrane, J. (2005). The risk and return to venture capital. Journal of Financial Economics, 71(1), 3-52.

Coviello, N.E. (2006). The network dynamics of international new ventures. Journal of International Business Studies, 37, 713-731.

Cumming, D.J., Fleming, G., \& Schwienbacher, A. (2006). Legality and venture capital exits. Journal of Corporate Finance, 12, 214-245.

Cumming, D.J. \& Johan, S.A. (2009). Venture capital and private equity financial contracting: An international perspective. Amsterdam: Elsevier Science Academic Press.

Cumming, D.J. \& MacIntosh, J.G. (2003). A cross-country comparison of full and partial venture capital exits. Journal of Banking and Finance, 27, 511-548.

Cumming, D.J. \& Walz, U. (2009). Private equity returns and disclosure around the world. Journal of International Business Studies, forthcoming.

De Clercq, D. \& Sapienza, H.J. (2005). When do venture capital firms learn from their investments? Entrepreneurship Theory and Practice, 29(4), 517-535.

De Clercq, D., Sapienza, H.J., \& Crijns, H. (2005). The internationalization of small and medium-sized firms: The role of organizational learning effort and entrepreneurial orientation. Small Business Economics, 24, 409-419.

Doidge, C., Karolyi, G.A., \& Stulz, R.M. (2004). Why are foreign firms listed in the U.S. worth more? Journal of Financial Economics, 71, 205-238.

Domowitz, I., Glen, J., \& Madhavan, A. (1998). International cross-listing and order-flow migration: Evidence from Mexico. Journal of Finance, 53, 2001-2028.

Dumev, A. \& Kim, E.H. (2005). To steal or not to steal: Firm attributes, legal environment and valuation. Journal of Finance, 60, 1461-1493.

Fernandez, Z. \& Nieto, M.J. (2006). Impact of ownership on the international involvement of SMEs. Journal of International Business Studies, 37, 340-351.

Foerster, S. \& Karolyi, G.A. (1993). International listings of stocks: The case of Canada and the U.S. Journal of International Business Studies, 24, 763-784. 
Foerster, S. \& Karolyi, G.A. (1998). Multimarket trading and liquidity: A transactions data analysis of Canada-U.S. interlistings. Journal of International Financial Markets, Institutions and Money, 8, 393-412.

Foerster, S. \& Karolyi, G.A. (1999). The effects of market segmentation and investor recognition on asset prices: Evidence from foreign stocks listing in the United States. Journal of Finance, 54, 981-1013.

Ghosh, C., Rodriguez, M., \& Sirmans, C.F. (1995). Gains from corporate headquarters relocations: Evidence from the stock market. Journal of Urban Economics, 38, 291-311.

Ginarte, J.C. \& Park, W.G. (1997). Determinants of patent rights: A cross-national study. Research Policy, 26, 283-301.

Goerzen, A. \& Makino, S. (2007). Multinational corporation internationalization in the service sector: A study of Japanese trading companies. Journal of International Business Studies, 38, 1149-1169.

Gompers, P., Lerner, J., \& Scharfstein, D. (2005). Entrepreneurial spawning: Public corporations and the formation of new ventures, 1986-1999. Journal of Finance, 60, 577-614.

Gompers, P.A. \& Lerner, J. (1999). The venture capital cycle. Cambridge, MA: MIT Press.

Guler, I. \& Guillen, M.F. (2006). Institutions, networks, and organizational growth. Working Paper. Charlotte, NC, and Philadelphia: University of North Carolina at Chapel Hill and University of Pennsylvania.

Heckman, J. (1976). The common structure of statistical models of truncation, sample selection, and limited dependent variables and a simple estimator for such models. Annals of Economic and Social Measurement, 5 , 475-492.

Heckman, J. (1979). Sample selection bias as a specification error. Econometrica, 47, 153-161.

Hege, U., Palomino, F., \& Schwienbacher, A. (2009). "Determinants of venture capital cerformance: Europe and the United States." Revue Finance, forthcoming.

Hsu, D. (2004). What do entrepreneurs pay for venture capital affiliation? Journal of Finance, 59, $1805-1844$.

Jääskeläinen, M. \& Maula, M. (2005). The effects of direct and indirect foreign venture capital ties on exit market selection and exit modes. Working Paper. Helsinki: Helsinki University of Technology.

Jayaraman, N., Shastri, K., \& Tandon, K. (1993). The impact of international cross-listings on risk and return: Evidence from American Depositary Receipts. Journal of Banking and Finance, 17, 91-103.

Kanniainen, V. \& Keuschnigg, C. (2003). The optimal portfolio of start-up firms in venture capital finance. Journal of Corporate Finance, 9, 521-534.

Kanniainen, V. \& Keuschnigg, C. (2004). Start-up investment with scarce venture capital support. Journal of Banking and Finance, 28, 1935-1959.

Kaplan, S. \& Schoar, S. (2005). Private equity returns: Returns, persistence and capital flows. Journal of Finance, 60, 1791-1823.

Keuschnigg, C. (2003). Optimal public policy for venture capital backed innovation. CEPR Working Paper No. 3850. London: Centre for Economic Policy Research.

Keuschnigg, C. (2004a). Venture capital backed growth. Journal of Economic Growth, 9, $239-261$.

Keuschnigg, C. (2004b). Taxation of a venture capitalist with a portfolio of firms. Oxford Economic Papers, 56, 285-306.

Keuschnigg, C. \& Nielsen, S.B. (2001). Public policy for venture capital. International Tax and Public Finance, 8, 557-572. 
Keuschnigg, C. \& Nielsen, S.B. (2003a). Tax policy, venture capital and entrepreneurship. Journal of Public Economics, 87, 175-203.

Keuschnigg, C. \& Nielsen, S.B. (2003b). Taxes and venture capital support. Review of Finance, 7, 515-538.

Keuschnigg, C. \& Nielsen, S.B. (2004). Start-ups, venture capitalists and the capital gains tax. Journal of Public Economics, 88, 1011-1042.

Knight, G. \& Cavusgil, S.T. (1996). The born global firm: A challenge to traditional internationalization theory. In S. Zou (Ed.), Advances in international marketing (pp. 11-26). Greenwich, CT: JAI Press.

Knight, G.G. \& Cavusgil, S.T. (2004). Innovation, organizational capabilities, and the born-global firm. Journal of International Business Studies, 35, 124-141.

La Porta, R., Lopez-De-Silanes, F., Shleifer, A., \& Vishny, R. (1997). Legal determinants of external finance. Journal of Finance, 52, 1131-1150.

La Porta, R., Lopez-De-Silanes, F., Shleifer, A., \& Vishny, R. (1998). Law and finance. Journal of Political Economy, 106, 1113-1155.

La Porta, R., Lopez-De-Silanes, F., Shleifer, A., \& Vishny, R. (2000). Agency problems and dividend policies around the world. Journal of Finance, 55, 1-34.

Lerner, J. \& Schoar, A. (2005). Does legal enforcement affect financial transactions? The contractual channel in private equity. The Quarterly Journal of Economics, 120, 223-246.

Lockett, A. \& Wright, M. (1999). The syndication of private equity: Evidence from the U.K. Venture Capital. International Journal of Entrepreneurial Finance, 1, 303-324.

Lockett, A. \& Wright, M. (2001). The syndication of venture capital investments. Omega: The International Journal of Management Science, 29, 375-390.

Lockett, A., Wright, M., Burows, A., Scholes, L., \& Paton, D. (2008). The export intensity of venture capital backed companies. Small Business Economics, 31, 39-58.

Madsen, T.K. \& Servais, P. (1997). The internationalization of born globals: An evolutionary process? International Business Review, 6, 561-583.

Manigart, S., De Waele, K., Wright, M., Robbie, K., Desbrières, P., Sapienza, H., et al. (2000). Venture capital, investment appraisal, and accounting information: A comparative study of the US, UK, France, Belgium and Holland. European Financial Management, 6, 380-404.

Manigart, S., DeWaele, K., Wright, M., Robbie, K., Desbrieres, P., Sapienza, H.J., et al. (2002). The determinants of the required returns in venture capital investments: A five-country study. Journal of Business Venturing, 17, 291-312.

Manigart, S., Korsgaard, M.A., Folger, R., Sapienza, H., \& Baeyens, K. (2002). The impact of trust on private equity contracts. Working Paper. Gent: Vlerick Leuven Gent Management School.

Manigart, S., Lockett, A., Meuleman, M., Desbrières, P., Landström, H., \& Wright, M. (2006). The syndication of venture capital investments. Entrepreneurship Theory and Practice, 30, 131-153.

Megginson, W.L. (2004). Towards a global model of venture capital? Journal of Applied Corporate Finance, $16,8-26$.

Megginson, W.L. \& Weiss, K.A. (1991). Venture capitalist certification in initial public offerings. Journal of Finance, 46, 879-903. 
Meschi, P.-X. (2005). Stock market valuation of joint-venture sell-offs. Journal of International Business Studies, 36, 688-700.

Neus, W. \& Walz, U. (2005). Exit timing of venture capitalists in the course of an initial public offering. Journal of Financial Intermediation, 14, 253-277.

Nikoskelainen, E. \& Wright, M. (2007). The impact of corporate governance mechanisms on value increase in leveraged buyouts. Journal of Corporate Finance, 13, 511-537.

Oviatt, B. \& McDougall, P. (1994). Toward a theory of international new ventures. Journal of International Business Studies, 25, 45-64.

Oviatt, B. \& McDougall, P. (1995). Global start-ups: Entrepreneurs on a world-wide stage. Academy of Management Review, 9, 30-44.

Phelan, S.E., Dalgic, T., Li, D. \& Sethi, D. (2006). The development of entrepreneurial networks: A necessary condition for international new ventures? Strategic Management Reviews, 0, 1-21.

Poterba, J. (1989a). Capital gains tax policy towards entrepreneurship. National Tax Journal, 42, 375-389.

Poterba, J. (1989b). Venture capital and capital gains taxation. In L.H. Summers (Ed.), Tax policy and the economy (Vol. 3, pp. 47-67). Cambridge, MA: MIT Press.

Puhani, P.A. (2000). The Heckman correction for sample selection and its critique. Journal of Economic Surveys, 14, 53-68.

Reece, W. \& Weisbach, M. (2002). Protection of minority shareholder interests, cross-listings in the United States, and subsequent equity offerings. Journal of Financial Economics, 66, 65-104.

Rialp, A., Rialp, J., \& Knight, G.A. (2005). The phenomenon of early internationalizing firms: What do we know after a decade (1993-2003) of scientific enquiry? International Business Review, 14, 147-166.

Sapienza, H., Manigart, S., \& Vermeir, W. (1996). Venture capital governance and value-added in four countries. Journal of Business Venturing, 11, 439-469.

Sapienza, H.J., Autio, E., George, G., \& Zahra, S. (2006). A capabilities perspective on the effects of new venture internationalization on survival and growth. Academy of Management Review, 31, 914-933.

Sapienza, H.J., De Clercq, D., \& Sandberg, W.R. (2005). Antecedents of international and domestic learning effort. Journal of Business Venturing, 20, 437-457.

Shleifer, A. \& Wolfenzon, D. (2002). Investor protection and equity markets. Journal of Financial Economics, 66, 3-27.

Tirtiroglu, D., Bhabra, H., \& Lel, U. (2004). Political uncertainty and asset valuation: Evidence from business relocations in Canada. Journal of Banking and Finance, 28, 2237-2258.

Wang, C.K. \& Sims, V. (2001). Exit strategies of venture capital-backed companies in Singapore. Venture Capital: An International Journal of Entrepreneurial Finance, 3, 337-358.

White, H. (1980). A heteroskedasticity-consistent covariance matrix estimator and a direct test for heteroskedasticity. Econometrica, 48, 817-838.

Wright, M. \& Lockett, A. (2003). The structure and management of alliances: Syndication in the venture Capital industry. Journal of Management Studies, 40, 2073-2104.

Wright, M., Hoskisson, R.E., Busenitz, L.W., \& Dial, J. (2001). Finance and management buyouts: Agency versus entrepreneurship perspectives. Venture Capital: An International Journal of Entrepreneurial Finance, $3,239-262$. 
Wright, M., Lockett, A., Pruthi, S., Manigart, M., Sapienza, H., Debrieres, P., et al. (2004). Venture capital investors, capital markets, valuation and information: US, Europe and Asia. Journal of International Entrepreneurship, 2, 305-326.

Wright, M., Pruthi, S., \& Lockett, A. (2005). International venture capital research: From cross country comparisons to crossing countries. International Journal of Management Reviews, 7, 135-165.

Zacharakis, A.L., McMullen, J.S., \& Shepherd, D.A. (2007). Venture capitalists' decision policies across three countries: An institutional theory perspective. Journal of International Business Studies, 38, 691-708.

Zacharakis, A.L. \& Shepherd, D.A. (2001). The nature of information and venture capitalists' overconfidence. Journal of Business Venturing, 16, 311-332.

Zacharakis, A.L. \& Shepherd, D.A. (2003). A non-additive decision-aid for venture capitalists' investment decisions. European Journal of Operational Research, 162, 673-689.

Zahra, S. (2005). A theory of international ventures: A decade of research. Journal of International Business Studies, 36, 20-28.

Zahra, S., Ireland, D., \& Hitt, M. (2000). International expansion, technological learning, and new venture performance. Academy of Management Journal, 43, 925-950.

Douglas Cumming is an associate professor and Ontario Research chair at York University-Schulich School of Business, 4700 Keele Street, Toronto, Ontario, Canada M3J 1P3.

Grant Fleming is a managing director at Wilshire Private Markets Group, P.O. Box 330, Canberra ACT 2601, Australia; and is a research associate at School of Finance and Applied Statistics, Australian National University, Canberra, Australia.

Armin Schwienbacher is an associate professor at LSM Université Catholique de Louvain, Louvain School of Management, Louvain-la-Neuve, Belgium; and is an assistant professor at University of Amsterdam, Roetersstraat 11, 1018 WB Amsterdam, The Netherlands.

We owe thanks to Michael Hertzel, Sofia Johan, and the seminar participants at the Australasian Banking and Finance Conference, Korea University Conference on Corporate Governance, the European Finance Association, and the National University of Singapore Business School for helpful comments. 